\title{
Evaluation of the Physicochemical and Biological Stability of Cetuximab under Various Stress Condition
}

\author{
Afsaneh Farjami ${ }^{\text {a, b }}$, Mohammadreza Siahi-Shadbad ${ }^{\mathrm{a}, \mathrm{b}}$, Parvin Akbarzadehlaleh ${ }^{\mathrm{a}}$, Khashayar Roshanzamir ${ }^{\mathrm{c}}$, Ommoleila \\ Molavid, a \\ ${ }^{a}$ Faculty of Pharmacy, Tabriz University of Medical Sciences, Tabriz, Iran. ${ }^{b}$ Food and Drug Safety Research Center, Tabriz \\ University of Medical Sciences, Tabriz, Iran. ${ }^{c}$ CinnaGen Medical Biotechnology Research center, Alborz University of \\ Medical Sciences, Karaj, Iran. ${ }^{\mathrm{d}}$ Biotechnology Research Center, Tabriz University of Medical Sciences, Tabriz, Iran.
}

Received, February 14, 2019; Revised, April 22, 2019; Accepted, April 23, 2019; Published, April 29, 2019.

ABSTRACT - Cetuximab is a chimeric monoclonal antibody against epidermal growth factor receptor (EGFR) and it is approved for treatment of human colorectal cancer and squamous cell carcinoma of head and neck. The aim of this research was to study the stability of cetuximab finish product $(5 \mathrm{mg} / \mathrm{mL})$ under various stress conditions including mechanical, thermal, light stress, and various freeze-thaw cycles. To determine the effects of environmental stresses on the physicochemical properties and bioactivity of cetuximab, a combination of physicochemical and cell-based biological methods including size exclusion chromatography (SEC), cation exchange chromatography (CEX), flow cytometry-based binding assay, and MTS cell viability/proliferation assay was used. The results obtained by the SEC and CEX methods revealed that incubation of cetuximab at 25 and 30 ${ }^{\circ} \mathrm{C}$, shaking, and various freeze-thaw cycles caused no physicochemical instability. However, functional analysis of the samples exposed to the above-mentioned conditions revealed a significant decrease in the bioactivity of cetuximab indicated by a significant reduction in the cell binding and growth inhibitory effects of cetuximab in EGFR overexpressing cancer cell line (A431). Incubation of cetuximab at 40 and $50{ }^{\circ} \mathrm{C}$ led to polymerization and fragmentation of the $\mathrm{mAb}$ and resulted in a significant decrease in the bioactivity of the $\mathrm{mAb}$. Our findings show that the light exposure had the most destructive effects on physicochemical and biological characteristics of cetuximab. In conclusion, we found that all mentioned stress conditions significantly affect the bioactivity of cetuximab. Our finding highlights the importance of bioactivity evaluation of biopharmaceuticals in their quality control assessment.

\section{INTRODUCTION}

Monoclonal antibodies (mAbs) are considered to be a therapeutic revolution, owing to their ability to bind antigens with high specificity and thereby modify their functions (1-3). Since 1992 when the United State Food and Drug Administration (FDA) approved the first therapeutic mAb (Orthoclone OKT3), as of 2018, FDA has approved 80 therapeutic $\mathrm{mAbs}$ for the treatment cancers, autoimmune conditions, infectious diseases, and organ transplantation (4-6).

Therapeutic proteins might encounter various types of stress during production, shipping, storage and final administration. Despite the high quality of current biopharmaceuticals formulations, a major concern with the use of therapeutic proteins is their propensity to degrade during long-term storage and/or during accidental exposure to environmental stresses such as temperature change, shaking, light exposure, variations in ionic strength, exposure to oxygen or to traces of metals and freeze-thaw cycles $(7,8)$. These stresses can change the physicochemical properties of biopharmaceuticals and can lead to the loss of their therapeutic effects (9). The therapeutic proteins degrade through more complex pathways as compared with classical drugs, which include: (i) physical instability due to denaturation, aggregation or adsorption on surfaces and (ii) chemical instability caused by hydrolysis, isomerisation, desamidation, disulfide bond breakage, non-disulfide crosslinking, or deglycosylation (10). Physical and chemical modification of biopharmaceuticals not only can lead to the loss of their bioactivity, but it can enhance their immunogenicity which in turn can cause severe hypersensitivity reactions such as anaphylaxis (11).

Corresponding Author: Dr. Ommoleila Molavi, Department of Pharmaceutical Biotechnology, Faculty of Pharmacy, Tabriz University of Medical Sciences, Tabriz-Iran, E-mail: omolavi@ualberta.ca 
Therefore, study of environmental stresses which can cause instability of biopharmaceuticals is an important step in developing strategies to preserve their physicochemical and functional characteristics throughout their production, storage, and delivery to the consumers.

The information obtained from the forced degradation study could be used to determine the intrinsic stability of drug substances and provide valuable information on the nature of degradation pathways and identification of degradation products (12). Since mAbs are subjected to a variety of degradation pathways, no single technique can satisfactorily provide sufficient information about different mechanisms by which mAbs are altered. Therefore, a wide range of analytical and biophysical techniques are required to monitor physicochemical stability, content/potency, and purity of biopharmaceutical proteins (13). To this end, appropriate orthogonal techniques including combination of physicochemical, immunological, and biological methods which are capable of detecting and quantifying the different degradation products; are beneficial to demonstrate product quality $(9,14-16)$.

Cetuximab, a chimeric $\mathrm{mAb}$ is an epidermal growth factor receptor (EGFR) inhibitor approved for the treatment of metastatic non-small cell lung cancer, metastatic colorectal cancer, and head and neck cancer (17). Cetuximab and other EGFR inhibitors show cell growth inhibitory effects in tumors with wild-type KRAS which encodes a small $\mathrm{G}$ protein and mediates the activation of the EGFR downstream signaling pathway. In normal cells, binding of growth factors to their receptors on the surface of the cells activates mitogen activated protein kinase (MAPK) pathway leading to cell proliferation. In some of the cancer cells, EGFR receptors and/or signaling molecules (i.e KRAS) get mutated leading to the activation of EGFR downstream signaling pathway in the absence of EGFR receptor ligation. In the cells with mutated EGFR receptor and wild type KRAS, cetuximab binds to this receptor and suppresses cell proliferation. However, cetuximab doesn't suppress EGFR downstream signaling pathway and cell proliferation in the cancer cells with mutated KRAS $(18,19)$. Therefore, its biological activity needs to be assessed in cancer cells which express high level of EGFR (20) and have no mutations on KRAS protein (21).
As the biological effects of the therapeutic antibodies specific to the cell surface receptors (i.e cetuximab) are mediated by binding of the antibody to the receptor and inhibition of the receptor activation, in vitro target binding assay is considered as a bioassay of choice in product quality control process. Besides, since EGFR receptors inhibitory antibodies suppress cell proliferation in cancer cells overexpressing this receptor, functional analysis of these antibodies can be done by assessment of their effect on cell proliferation by cell-based potency assays. This type of potency tests can determine differences in biopharmaceutical quality which are not revealed in binding assays. Therefore, cell-based potency assays are mostly essential and usually preferred by regulatory authorities $(22,23)$. While there are some reports on the evaluation of cetuximab physicochemical stability and bioactivity under a limited number of stress conditions $(24,25)$, to our knowledge, there hasn't been any comprehensive study using cell-based assays to evaluate the biological activity of cetuximab exposed to various stress condition. In this research, we have used different types of analytical methods and cellbased assays to evaluate the effects of various stress conditions on the physicochemical properties and biological activity of cetuximab. To this end, the finish products of cetuximab $5 \mathrm{mg} / \mathrm{mL}$ was incubated under variety of environmental stresses including elevated temperature, shaking, high light intensity and various freeze-thaw cycles. Size exclusion chromatography (SEC) and cation exchange chromatography (CEX) were used to determine changes in physicochemical properties of stressed samples. The biological activity of cetuximab exposed to environmental stress, was evaluated in EGFR overexpressing cancer cells by two methods including flow cytomerty-based cells binding assay and MTS cell proliferation test.

\section{METHOD AND MATERIALS}

\section{Materials}

The mAb used in this study was Cetuximab (Araxya, CinnaGen, Iran) which was kindly provided by CinnaGen Medical Biotechnology Center. Erbitux (Merck KGaA, Germany) was used as a representative cetuximab reference standard. According to the indications, the content of the active ingredient in each $\mathrm{mL}$ of finish product of Erbitux and Araxya is $5 \mathrm{mg}$. For performing experiments, 
low binding injection vials with the nominal size of $2 \mathrm{R}$ containing $1 \mathrm{ml}$ of cetuximab's finished product which were aliquoted and sealed by CinnaGen Medical Biotechnology Center were used. It should be noted that cetuximab is recommended to be stored in the refrigerator at $2-8{ }^{\circ} \mathrm{C}$, protected from moisture and light. For the buffers preparation, sodium chloride, disodium hydrogen phosphate $\left(\mathrm{Na}_{2} \mathrm{HPO}_{4}\right)$ and sodium hydroxide were purchased from Merck, Germany. Ortho-Phosphoric acid (purity of 85\%) was purchased from Sigma-Aldrich.

\section{Cell culture}

Human epidermoid carcinoma cell line A431 was obtained from Pasteur Institute of Iran (National Cell Bank of Iran (NCBI), ATCC Number: CRL-1555). A431 cells were cultured in monolayers in RPMI growth medium, supplemented with $10 \%$ of Fetal Bovine Serum (FBS) at $37{ }^{\circ} \mathrm{C}$ in a humidified $\mathrm{CO}_{2}$ incubator $\left(5 \% \mathrm{CO}_{2}\right)$. The reagents for cell culture, such as powdered RPMI medium and FBS were acquired from Gibco (Thermo Fisher scientific, USA). Dimethyl sulfoxide (DMSO) was purchased from Sigma-Aldrich. [3-(4, 5-dimethylthiazol-2-yl)5-(3-carboxymethoxyphenyl)-2-(4-sulfophenyl)2H-tetrazolium, inner salt; (MTS) was acquired from Promega (Madison, USA). EGFR (R-1) FITC (sc101 FITC, a mouse monoclonal $\mathrm{IgG}_{2 b}$ provided at $200 \mu \mathrm{g} / \mathrm{ml}$ ) and normal mouse $\operatorname{IgG}_{2 \mathrm{~b}}$-FITC (sc-2857) were purchased from Santa Cruz Biotechnology (Santa Cruz, CA, USA). A mouse anti human IgGFITC (Azar Tak Clone, Iran) was used in flow cytometry-based binding assay.

\section{Analysis of EGFR expression level on the cell surface using flow cytometry}

Expression of EGFR on cell surface of A431 tumor cell line was evaluated using a flow cytometric system (MACSQuant Analyser 10, Miltenyi Biotec, Germany). For this purpose, in each micro-tube, $5 \times 10^{5}$ tumor cells were incubated with $20 \mu \mathrm{l}$ of EGFR mAb (R-1, sc-101 FITC) in 1\% FBS in phosphate-buffered saline (PBS) for $30 \mathrm{~min}$ at $4{ }^{\circ} \mathrm{C}$. After several washing steps, the tumor cells were resuspended in $0.5 \mathrm{~mL}$ PBS. Also, experiments were carried out with normal mouse IgG2b-FITC: sc-2857 as ISO Control and in absence of antibody as an unstained control. EGFR expression levels were evaluated by calculating the intensity of the FITC signal. Data acquisition and result compilation were performed by FlowJo X7 software.
Analysis of KRAS mutation in A431 tumor cells

KRAS mutations at exon 2, codons 12 and 13 were investigated in A431 tumor cells by a sensitive PCR assay. After extraction of the genomic DNA from the cells, the KRAS gene exon 2 was amplified by PCR (Eppendorf, Master cycler gradient, Germany) with the following primer set: 5 AAGGCCTGCTGAAAATGACTG - 3 and 5 TGGTCCTGCACCAGTAATATG- 3 .

Checking the amplification product was carried out on an agarose gel and then the PCR reaction was purified with the PCR Purification Kit (QIAquickR Gel Extraction Kit) and used for sequencing. Each PCR reaction had a $50 \mu \mathrm{L}$ volume and contained: 1 $\mu \mathrm{L}$ of genomic DNA, $1 \mu \mathrm{L}$ of the above-mentioned primer set, $5 \mu \mathrm{L}$ of $10 \mathrm{X}$ Standard Taq Reaction Buffer, $1 \mu \mathrm{L}$ of dNTPs $10 \mathrm{nM}, 0.8 \mu \mathrm{L}$ of Taq DNA Polymerase, $2.5 \mu \mathrm{L} \mathrm{Mgc12}$ and Nuclease-free water. The PCR reaction program was as follows: initial denaturation $\left(5 \mathrm{~min}\right.$ at $95{ }^{\circ} \mathrm{C}$ for activating the Taq DNA Polymerase), followed by 40 cycles of denaturation $\left(1 \mathrm{~min}\right.$ at $\left.95{ }^{\circ} \mathrm{C}\right)$, annealing of the primer to the template $\left(50\right.$ seconds at $\left.55^{\circ} \mathrm{C}\right)$, and elongation $\left(90\right.$ seconds at $\left.72{ }^{\circ} \mathrm{C}\right)$. After the last cycle, a final extension $\left(10 \mathrm{~min}\right.$ at $\left.72{ }^{\circ} \mathrm{C}\right)$ was added, and then the PCR reaction was cooled down to $4{ }^{\circ} \mathrm{C}$. The PCR products after purification were sent to Pishgam Biotech Company for sequencing.

\section{Exposure of the antibody to the environmental stress}

\section{Shaking stress}

To study the effects of shaking on stability of cetuximab, the filled vials were placed horizontally on the shaker (Padideh Nojen Pars, Iran) platform and agitated. Shaking intensities of $150 \mathrm{rpm}$ (round per minute) and $250 \mathrm{rpm}$ were used. The temperature was adjusted to $25{ }^{\circ} \mathrm{C} \pm 1$. Furthermore, the experiments were conducted at $4{ }^{\circ} \mathrm{C} \pm 1$ to determine the effects of shaking stress on the mAb stability in the absence of any other environmental stress (i.e ambient temperature). At predefined time points ( 0 , $1,6,12,24$ and $48 \mathrm{~h}) ; 200 \mu \mathrm{L}$ of stressed cetuximab was removed from the vials. It should be noted that to test the effects of shaking, sampling form the vials was done under laminar airflow to avoid the bacterial contamination. Three unstressed samples were analyzed as control.

\section{Thermal stress}

The filled vials were incubated at 25, 30, 40 and 50 ${ }^{\circ} \mathrm{C} \pm 1$ for assessing the effects of high temperature 
on cetuximab stability. All vials were protected against light with aluminum foil. For each temperature, sampling was done at predefined points. $200 \mu \mathrm{L}$ of cetuximab was withdrawn from vials kept at 25,30 and $40{ }^{\circ} \mathrm{C} \pm 1$ at $1 \mathrm{~h}, 3 \mathrm{~h}, 6 \mathrm{~h}, 12$ h, 24 h, 48 h, 72 h, 1 week, 2 weeks, and 1-month time points. Sampling time point for vial kept at 50 ${ }^{\circ} \mathrm{C} \pm 1$ was $1 \mathrm{~h}, 3 \mathrm{~h}, 6 \mathrm{~h}, 12 \mathrm{~h}, 24 \mathrm{~h}, 48 \mathrm{~h}$ and $72 \mathrm{~h}$. All samplings were done under laminar airflow to avoid the bacterial contamination. Three unstressed samples were analyzed as control.

\section{Freeze-thaw cycles}

To study of the freeze-thaw cycles effect, the vials were placed for $24 \mathrm{~h}$ into a $-20{ }^{\circ} \mathrm{C}$ freezer. After freezing, the samples were thawed at room temperature. The freeze-thawing procedure was performed 5 times.

\section{Light stress}

The effects of light stress on cetuximab stability was investigated using photo-chamber (Pouya Tadbir Arnika trading, Iran) equipped with an auto-timer. This photo chamber provides independent exposure to visible and UV spectral regions. The applied photo-chamber is equipped with a cool white fluorescent lamp and near ultraviolet (UV) black lamp having spectral emission in approximately $350-400 \mathrm{~nm}$ with a peak at $370 \mathrm{~nm}$. The irradiance level was 5 watt /square meter $\left(\mathrm{W} / \mathrm{m}^{2}\right)$ for near UV light and 12000 lux for white light. According the ICH Q1B Photo-stability guideline for New Active Substances and Medicinal Products, overall illumination for confirmatory study should not be less than 1.2 million lux hours (h) and an integrated near ultraviolet energy of not less than $200 \mathrm{Wh} / \mathrm{m}^{2}$.

For this purpose, the filled vials exposed to light along with a dark control sample (wrapped in aluminum foil) at four stages. The intended visible and UV light level at each stage was as following:

First stage: 0.3 million luxh and $50 \mathrm{Wh} / \mathrm{m}^{2}$, second stage: 0.6 million luxh and $100 \mathrm{Wh} / \mathrm{m}^{2}$, third stage: 1.2 million luxh and $200 \mathrm{Wh} / \mathrm{m}^{2}$ (a required radiation for confirmatory study (3)), fourth stage: 1.8 million luxh and $300 \mathrm{Wh} / \mathrm{m}^{2}$.

All tests were done at $25{ }^{\circ} \mathrm{C}$. To determine the probable impact of the elevated temperature on tests results, a vial kept at refrigerated condition without light exposure as a reference standard was included throughout photos-stability study. The sampling was performed before light exposure on samples as control samples and at the end of each stage.

\section{Chromatographic analysis}

An Agilent 1260 infinity liquid chromatography (Waldbronn, Germany) was used for all Chromatographic analysis. The chromatography system is equipped with a photodiode array (PDA) detector, low-pressure quaternary gradient pump, degasser, and a thermal column compartment for precise temperature. Data acquisition and result compilation were done using ChemStation software. Metrohm pH meter (827 pH lab, Swiss) was used for the adjustment of the mobile phase $\mathrm{pH}$.

\section{Cation exchange chromatography (CEX)}

Salt gradient based CEX chromatography was performed using the previously developed and validated method by Farjami et al (26). In brief, weak cation exchange column (ProPac WCX-10 G, 4 $\mathrm{mm} \times 250 \mathrm{~mm}, 10 \mu \mathrm{m}$ particle size, non-porous, Thermo scientific, Dionex Corporation) with guard column was used. Buffer A was prepared with 20 $\mathrm{mM} \mathrm{KH}_{2} \mathrm{PO}_{4} \mathrm{pH} 6.2$, and buffer B was prepared with $20 \mathrm{mM} \mathrm{KH} \mathrm{PO}_{4}$ and $500 \mathrm{mM}$ sodium chloride $\mathrm{pH}$ 6.2 , both in deionized water. The flow rate was 1 $\mathrm{mL} / \mathrm{min}$, and the injected volume was $20 \mu \mathrm{L}$. The elution gradient started with $100 \%$ of A to achieve $80 \%$ of $\mathrm{A}$ and $20 \%$ of B within $40 \mathrm{~min}$, followed by an equilibrium phase of $5 \mathrm{~min}$ to obtain $100 \%$ of buffer A. Chromatograms were registered at $\lambda=210$ $\mathrm{nm}$, using $\lambda=500 \pm 20 \mathrm{~nm}$ as the reference wavelength. The mean value of the area under the curve (AUC) and the retention time were compared to those of the reference sample. The protein recovery was calculated by comparing the total AUC of stressed samples at $210 \mathrm{~nm}$ with the total AUC of the non-stressed sample, which was set to $100 \%$.

\section{Size exclusion chromatography (SEC)}

We have developed and validated a SEC method for quantitative and qualitative analysis of cetuximab (27). To this end, TSKgel ${ }^{\circledR}$ G3000SWxl column (7.8 $\mathrm{mm} \times 300 \mathrm{~nm}$, Tosoh Biosciences Corporation, King of Prussia, PA 19406, USA) and the elution was monitored at $210 \mathrm{~nm}$. A total of $20 \mu \mathrm{L}$ of each centrifuged sample were eluted isocratically with buffer containing $0.05 \mathrm{M}$ disodium hydrogen phosphate $\left(\mathrm{Na}_{2} \mathrm{HPO}_{4}\right)$ and $0.15 \mathrm{M}$ Sodium chloride $(\mathrm{w} / \mathrm{v})$ at $\mathrm{pH}$ 7.4. The flow rate of $1.00 \mathrm{~mL} / \mathrm{min}$ was applied. The temperature was maintained at $25{ }^{\circ} \mathrm{C}$. The AUC, the retention time and the molecular weight were studied. The molecular weight of each obtained peak was estimated using a standard solutions of gel filtration markers kit (Sigma Aldrich. 
St. louis. USA) including some molecular weight markers ranging from 29 to $2000 \mathrm{kDa}$ (Carbonic Anhydrase from bovine erythrocytes $(29 \mathrm{kDa})$, Bovine serum albumin (66 kDa), b-Amylase from sweet potato $(200 \mathrm{kDa})$, Apoferritin from horse spleen (443 kDa), Thyroglobulin bovine $(669 \mathrm{kDa})$, Blue Dextran (2,000 kDa)). The experiment showed that there was a logarithmic relationship between the molecular weight and the retention time of each molecular weight marker. A calibration curve was drawn by plotting elution volume against $\log$ of molecular weight.

\section{Cell viability and proliferation assay to evaluate cetuximab bioactivity}

To assess the bioactivity of cetuximab under various stress condition, the cell growth inhibitory effects of the mAb was evaluated in A431 cell line using MTS assay. To this end, $100 \mu \mathrm{L}$ aliquot of the cell suspension equal to $0.3 \times 10^{5}$ cells per $\mathrm{mL}$ in each well of a 96-well plate was cultured and treated with cetuximab at various concentrations for three days. To evaluate cell viability, $20 \mu \mathrm{L}$ of a MTS solution was added to each well and the cells were incubated at $37{ }^{\circ} \mathrm{C}$ and $5 \% \mathrm{CO}_{2}$ for $4 \mathrm{~h}$. The absorbance of each well was recorded at $490 \mathrm{~nm}$ with a 96-well plate reader (BioTek, synergy HT, USA). The percent of MTS reduction was calculated as follows:

$\%$ MTS reduction $=[$ absorbance of treated cells $/$ absorbance of untreated control] $\times 100$

The half maximum growth inhibitory concentration $\left(\mathrm{IC}_{50}\right)$ of cetuximab was calculated from the obtained dose-response curve. All experiments were performed in triplicate. To detect potential changes in bioactivity of cetuximab after exposing to stress conditions, three wells were seeded for each degraded sample at concentration obtained for $\mathrm{IC}_{50}$.

\section{EGFR-binding analysis of stressed cetuximab using flow cytometry}

The binding of cetuximab to tumor cell line (A431) was titrated using flow cytometry. Cetuximab was used as the primary antibody. 500,000 A431 cells were placed in each centrifuge tube and washed twice with $0.5 \mathrm{~mL}$ of $1 \%$ ice-cold bovine serum albumin in PBS (flow cytometry buffer). Then, tumor cells were incubated with $5 \mu \mathrm{g}$ of $1 \mathrm{mg} / \mathrm{mL}$ cetuximab in flow cytometry buffer for $30 \mathrm{~min}$ at 4 ${ }^{\circ} \mathrm{C}$ and then washed twice with ice-cold flow cytometry buffer. After staining with the primary antibody (cetuximab), $2 \mu \mathrm{g}$ fluorescein-conjugated mouse antihuman IgG as the secondary antibody was added to the cells and incubated for $30 \mathrm{~min}$ at $4{ }^{\circ} \mathrm{C}$ in the dark. The cells were then washed three times with ice-cold flow cytometry buffer and were resuspended in $0.5 \mathrm{~mL}$ flow cytometry buffer at the end of the third wash. Control experiments were carried out in the absence of primary antibody as unstained control. Cetuximab binding levels to A431 cells were evaluated by calculating the intensity of the FITC signal. Data were analyzed with FlowJo X7 software.

The antibody test samples used in the bioactivity assays were the samples which were exposed to various stress conditions and had already been evaluated for physicochemical stability by chromatographic analysis.

\section{STATISTICAL ANALYSIS}

The results are presented as mean \pm standard deviation (SD) obtained from three independent experiments. Where possible and appropriate, the data were analyzed for statistical significance using unpaired Student's t-test or one-way analysis of variance (ANOVA) followed by post hoc Tukey test. The level of statistical significance was defined as $p$ $<0.05$. All data were analyzed with the GraphPad Prism Software vs. 6.0 (GraphPad Software Inc.).

\section{RESULTS}

\section{Size exclusion chromatography (SEC)}

A common and trouble manifestation of protein instability is aggregation which is formation of abnormal association into larger soluble or insoluble aggregate structure rendering an inhomogeneous group of instability products in varying size and morphology. Protein aggregation may be formed by simple physical association with each other without any covalent bond formation and change in the primary structure (physical aggregation) or by a new covalent bond formation leading to a structural change (chemical aggregation) (28). Based on the WHO standards, an aggregate level of less than $5 \%$ is acceptable in commercial intravenous immunoglobulin products (29).

While a broad size range of aggregates from nanometer to hundreds of microns requires a wide variety of analytical techniques to characterize the aggregates, SEC is still a first choice and powerful 
technique for monitoring small nanometer-sized soluble aggregates based on high throughput, precision and simplicity. This method is fast and timesaving $(<30 \mathrm{~min})$, with reasonable peaks in the chromatogram for monomer and high order aggregate which are simply detected and quantified (30).

In size exclusion chromatogram of cetuximab, only one peak at retention time of $7.6 \pm 0.01 \mathrm{~min}$ for the cetuximab reference sample was found. The molecular weight calculated using equation was $157.8 \pm 1.0 \mathrm{kDa}$, as expected (31). Two other peaks at retention time of 11.1 and $11.7 \mathrm{~min}$ were observed for all samples corresponding to the buffer components (Figure 1a). Comparing signal intensities of different wavelengths obtained by PDA detector resulted in selection of $210 \mathrm{~nm}$ as an ideal wavelength for obtaining the chromatograms.

\section{Cation exchange chromatography (CEX)}

Chemical stability of cetuximab was assessed by previously developed CEX liquid chromatography method (26), which can separate the charge variants of a protein. Cetuximab is a heterogeneous $\mathrm{mAb}$ owning two N-glycosylation sites on each heavy chain. Presence of C-terminal lysines and charged glycans containing sialic acid are the prominent reasons for the occurrence of different charge variants. Cetuximab has several isoforms including acidic variants (eluting before the main peak), main peak and basic variants (eluting after the main peak). CEX chromatograms of cetuximab presented a specific profile with 8 different isoforms (Figure 1b).

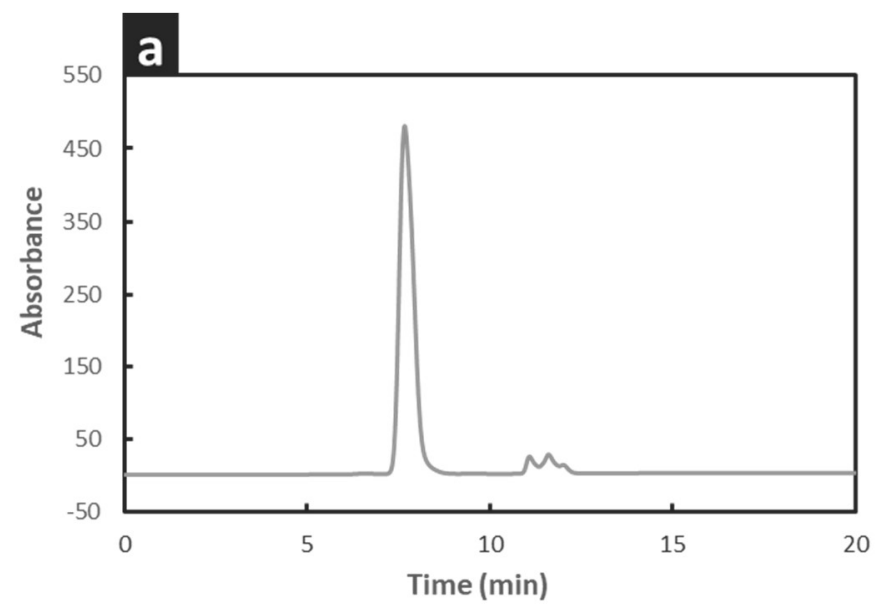

Functional analysis of Cetuximab in A431 cell line According to ICH Q5C, guideline about stability testing of biotechnological/biological products, "assays for biological activity, where applicable, should be part of the pivotal stability studies" (32). To study the stability of biopharmaceuticals, physicochemical techniques are powerful methods to define purity, identity and integrity of products. Nevertheless, the obtained results cannot be attributed to the bioactivity, as physicochemical methods cannot assess the higher order structure of the biopharmaceutical sufficiently. Thus appropriate bioassays based on mechanism of action are generally required to determine the potency of a biopharmaceutical and confirm the physicochemical analyses (33). In this research in addition to chromatographic analyses to determine physicochemical change in $\mathrm{mAb}$ structure, bioactivity of cetuximab was evaluated by cell binding and cell toxicity analyses in A431, an EGFR overexpressing cell line.

One of the important assay to evaluate the bioactivity of a $\mathrm{mAb}$ is to test the binding of the product to its specific receptors or ligands. The binding assay evaluates the integrity of the regions of the test product molecule that are involved in that particular binding interaction [30]. Flow cytometry-based binding assay is widely used to characterize the biological activity of products through analysis of the interaction of fluorescently labeled ligands and their specific cellular receptors (34)

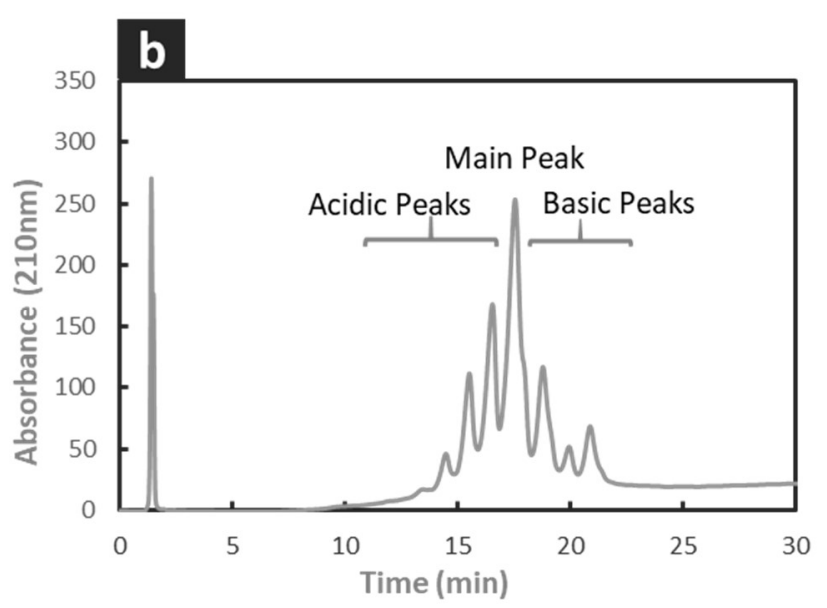

Figure 1. (a): Representative SEC chromatograms monitored at $210 \mathrm{~nm}$ of unstressed cetuximab (27). (b): Representative CEX chromatograms monitored at $210 \mathrm{~nm}$ of unstressed cetuximab with a pI value of 8.7. Multiple acidic and basic isoforms are depicted (26). 
Cetuximab acts through exclusively and high specificity binding of Fab fragment to domain III of EGFR and an epitope which partly overlaps the binding site of growth factor on domain III leading to inhibition of receptor dimerization and suppression of cell proliferation (35). In this project we assessed the binding of stressed $\mathrm{mAb}$ to its receptor (EGFR) in an EGFR overexpressing cell line (i.e A431) in comparison with that of control sample. The expression of EGFR in A431 cells was confirmed using flow cytometric analysis with an EGFR antibody conjugated with FITC. As it is shown in Figure 2, about $98 \%$ of A431 cells overexpress EGFR.

EGFR receptor activation by cetuximab induces cell growth through MAPK pathway and KRAS signaling protein is a key player in this pathway. Poor response to anti-EGFR therapies is associated with activating mutations in the KRAS gene which are found in $30-40 \%$ of colorectal tumors (19). Mutation in the codons 12 and 13 in the exon 2 of the KRAS gene generates an alternated constitutively active form of this protein which activates EGFR downstream signaling pathway and induces cell proliferation regardless of EGFR receptor ligation. Blocking EGFR receptor using anti-EGFR antibodies such as cetuximab, cannot suppress EGFR downstream signaling pathway and consequent uncontrolled cell proliferation in the cells with mutated KRAS (36). Therefore, we first used PCR assay to confirm that A431 cells have no mutation in KRAS and the obtained results by PCR and the following gene sequencing showed no KRAS mutation was found in the A431 cells. The results of EGFR expression and KRAS mutation analysis revealed that $\mathrm{A} 431$ is a suitable cell line to evaluate the growth inhibitory effects of cetuximab as it overexpresses EGFR and has no mutation in KRAS gene.

As cetuximab suppresses cell growth by blocking EGFR receptor, the bioactivity of this $\mathrm{mAb}$ was also measured by assessing its ability to reduce cell viability and proliferation in an EGFR overexpressing cancer cell line using MTS assay (i.e A431). The calculated $\mathrm{IC}_{50}$ for cetuximab in $\mathrm{A} 431$ cell line was $9.2 \pm 0.7 \mu \mathrm{M}$. To evaluate the effects of environmental stress on the bioactivity of cetuximab, the MTS proliferation assay was performed on the cells treated with the stressed samples at concentration of $9.2 \mu \mathrm{M}$ versus those treated with the intact molecule at the same concentration.

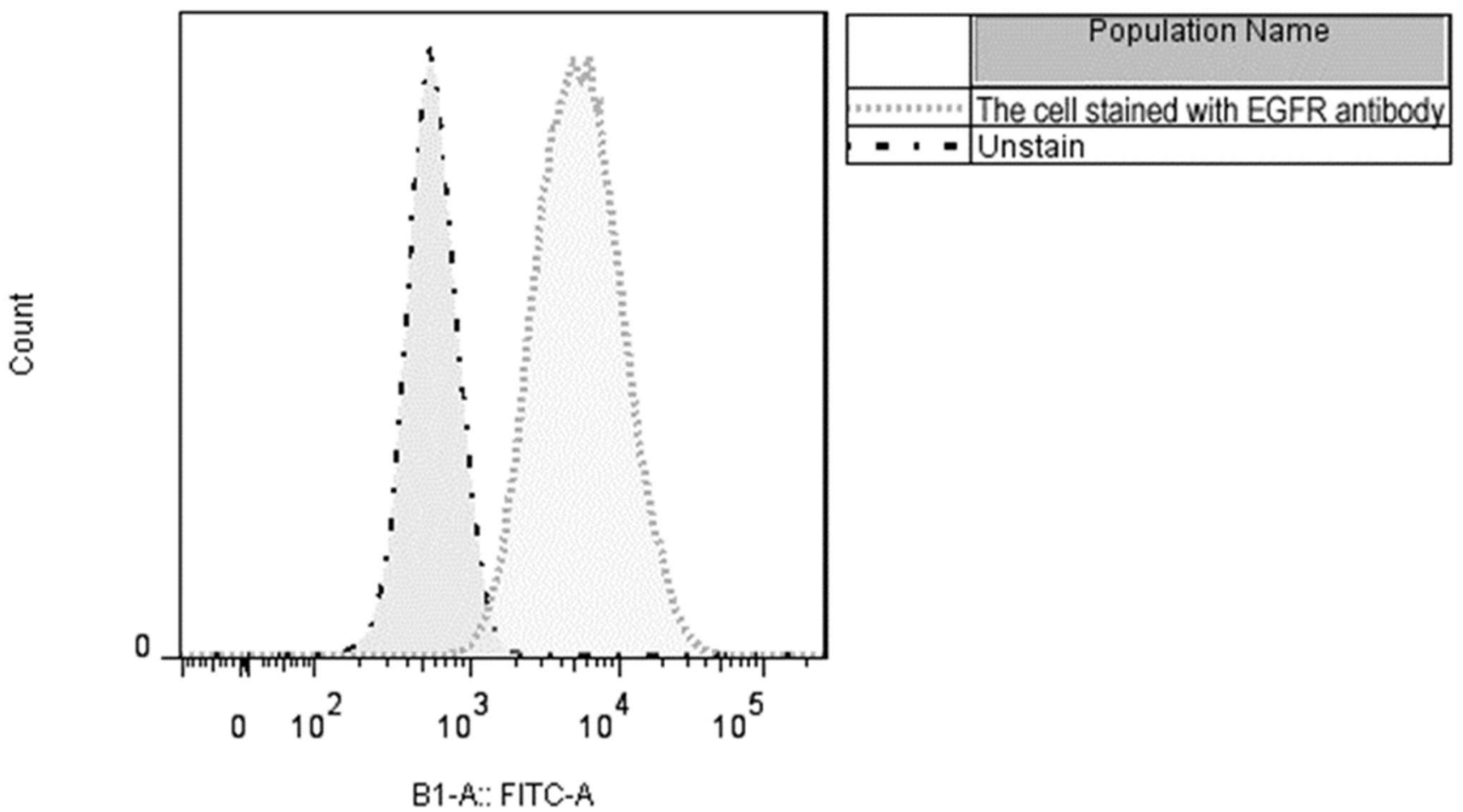

Figure 2. EGFR surface expression in A431 cell line. 


\section{Evaluation of cetuximab stability under shaking stress}

To evaluate the effects of shaking stress on cetuximab, the samples were exposed to shaking with 150 and $250 \mathrm{rpm}$ intensities at ambient temperature $\left(25 \pm 1{ }^{\circ} \mathrm{C}\right)$ and $4{ }^{\circ} \mathrm{C}$. Sampling was done at $0,1,6,24$ and $48 \mathrm{~h}$ for both shaking intensities. When cetuximab formulation was subjected to shaking at ambient temperature for $48 \mathrm{~h}$, no modifications in size exclusion profile and no unknown chromatographic peaks were observed. The chromatograms of the stressed mAb samples were similar to those of the control sample. The recovery of the stressed samples was close to $100 \%$ compared to the reference sample with the same concentration. We also studied the effect of shaking on cetuximab stability at refrigerated temperature (4 $\pm 1{ }^{\circ} \mathrm{C}$ ) which is the recommended storage temperature for cetuximab. Likewise, we found no changes in size exclusion profile of cetuximab exposed to physical stress at $4{ }^{\circ} \mathrm{C}$. In our study, shaking of cetuximab liquid formulation at 150 and $250 \mathrm{rpm}$ for $48 \mathrm{~h}$ revealed no significant change in its size exclusion chromatogram. We observed no additional peak, decrease in total AUC, and no change in peak shape and retention time in the $\mathrm{mAb}$ samples exposed to shaking stress. No polymerization or fragmentation detected by SEC method. Also, shaking stresses had no significant effect on charge heterogeneity profile of the stressed samples comparing to the control one. The chromatograms for the stressed samples were similar to those for the control. The recovery values were close to $100 \%$ for all of the stressed samples analysed.

As depicted in Figure 3a, shaking stress at room temperature had a severe negative effect on the binding of cetuximab to its receptor. The cell binding of $\mathrm{mAb}$ samples exposed to shaking at room temperature for $48 \mathrm{~h}$ decreased to $67 \%$ as compared with that of control sample being $97.6 \%$. In the other hand, shaking the mAb sample at $4{ }^{\circ} \mathrm{C}$ resulted in less severe effects on its cell binding as compared to the samples exposed to shaking at $25^{\circ} \mathrm{C}$. While the cell binding was $98.8 \%$ for the controls samples, it went down to $83.3 \%$ and $84.6 \%$ in the samples exposed to shaking with 150 and $250 \mathrm{rpm}$ at $4{ }^{\circ} \mathrm{C}$, respectively.

Our findings showed that, while shaking at 150 $\mathrm{rpm}$ at $25{ }^{\circ} \mathrm{C}$ for $12 \mathrm{~h}$ had no significant effect on A431 cells viability, the shaking stress with the same intensity for $24 \mathrm{~h}$ resulted in a significant increase $(p<0.05)$ in the cell viability of the cells treated with stressed $\mathrm{mAb}$ as compared with those treated with control sample (56.42\% versus 69.3\%) (Figure 3b). This observation indicated that the exposure of cetuximab to shaking stress at room temperature for 24 hours significantly reduces its biological function which is indicated by its growth inhibitory effects on cancer cells (unpaired Student's t-test, $\mathrm{p}<0.05$ ). Interestingly, no significant differences were found in the cell viability of cancer cells treated with the mAb samples shook at 150 and $250 \mathrm{rpm}$ at $4{ }^{\circ} \mathrm{C}$ as compared with those treated with the control. This observation indicates that the biological activity of the $\mathrm{mAb}$ samples remained constant when they are exposed to the shaking stress at $4{ }^{\circ} \mathrm{C}$.

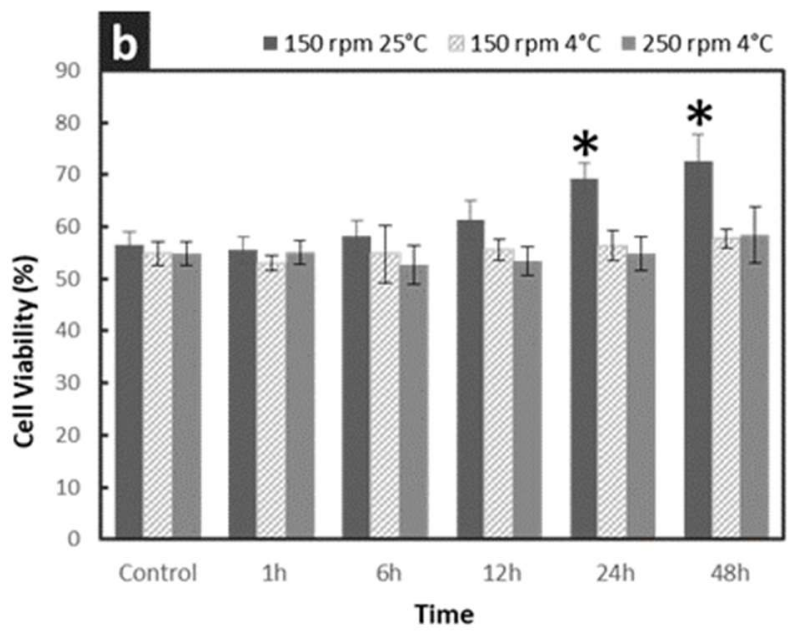

Figure 3. Alteration in bioactivity of cetuximab under shaking stress by (a): flow cytometric binding assay. I: Shaking at 150 $\mathrm{rpm}$ at $25{ }^{\circ} \mathrm{C}$, II: Shaking at $150 \mathrm{rpm}$ at $4{ }^{\circ} \mathrm{C}$, the data represent one out of three independent experiments which showed the similar results (b): MTS cell viability/proliferation assay. * Significantly different from control (unpaired student's t-test, $\mathrm{p}$ $<0.05$ ). 


\section{Assessment of cetuximab stability under thermal stress}

To assess the effects of thermal stress on cetuximab samples, the finished product of this $\mathrm{mAb}$ was incubated at various temperatures and then the physicochemical and biological activity of stressed samples were compared to that of control samples kept at $4{ }^{\circ} \mathrm{C}$. Our findings showed no significant changes in the chromatogram profile, AUC and retention time of the mAb samples stored at $25{ }^{\circ} \mathrm{C}$ and $30^{\circ} \mathrm{C}$ for a month as compared with the control sample. The recovery of all samples was close to $100 \%$. There was no insoluble aggregate or precipitation in the stressed samples.

In the next step, cetuximab samples were incubated at $40{ }^{\circ} \mathrm{C}$ up to $72 \mathrm{~h}$. While we did not observe any changes in the chromatogram profile, AUC and retention time of the mAb samples kept at $40{ }^{\circ} \mathrm{C}$ for $72 \mathrm{~h}$, incubation of the mAb samples at 40 ${ }^{\circ} \mathrm{C}$ for a week resulted in generation of 3 degradation products. These products included two high molecular weight species (HMWs) referred as
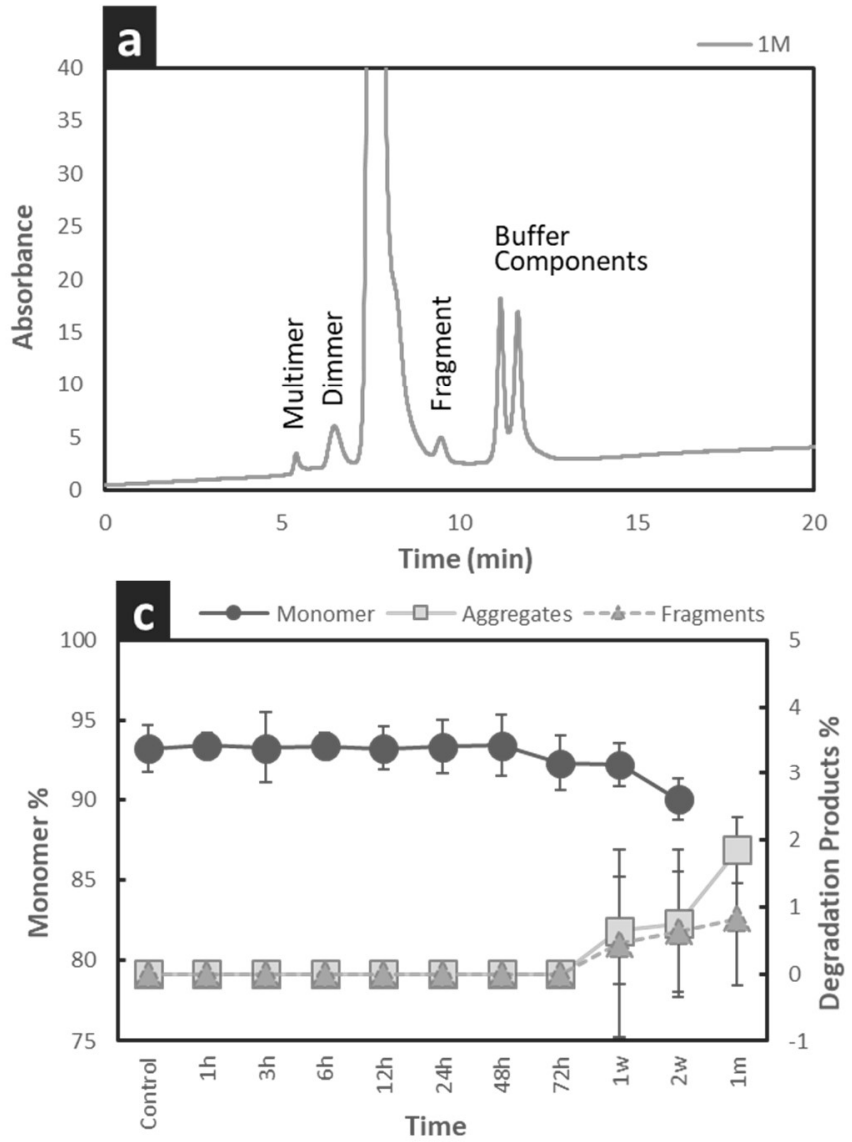

Figure 4. Representative SEC chromatograms monitored at $210 \mathrm{~nm}$ of cetuximab (a): Incubation at $40^{\circ} \mathrm{C}$ for $1 \mathrm{month}$. (b): Incubation at $50{ }^{\circ} \mathrm{C}$ for $72 \mathrm{~h}$. Plots of monomer loss and soluble aggregates and fragments formation as a function of (c): Incubation at $40^{\circ} \mathrm{C}$ for 1 month. (d): Incubation at $50{ }^{\circ} \mathrm{C}$ for $72 \mathrm{~h}$ measured by SEC aggregates and a one weak fragment. The aggregates eluted before the original peak at retention time of $5.4 \pm 0.01 \mathrm{~min}$ (labeled as multimer) and $6.5 \mathrm{~min}$ \pm 0.01 (labeled as dimer) and the fragment eluted after the original peak at retention time of $9.5 \pm 0.01$ min. The original peak representing cetuximab was labeled as monomer (Figure 4a). The molecular weight of multimer, dimer, monomer and fragment was calculated to be $852.0 \pm 1.6,373.9 \pm 1.4,157.8$ \pm 1.0 and $38.0 \pm 1.6 \mathrm{kDa}$ respectively. The peak area of 3 degradation products clearly increased until 1 month. After 1 month at $40{ }^{\circ} \mathrm{C}, 3 \%$ decrease in AUC of monomer was observed.

Monitoring of stressed cetuximab at $50{ }^{\circ} \mathrm{C}$ was ended after $72 \mathrm{~h}$ due to the precipitation and turbidity of liquid formulation. A minor aggregation detected by a peak observed at $5.4 \mathrm{~min}$ with molecular weight of $852.0 \pm 1.2$ after $1 \mathrm{~h}$ incubation (Figure $4 \mathrm{~b}$ ). Also, a minor fragment was observed at $9.5 \pm 0.03$ min with molecular weight of $38.0 \pm 1.1 \mathrm{kDa}$ after $72 \mathrm{~h}$ incubation at $50{ }^{\circ} \mathrm{C}$. The AUC of aggregate increased in the samples incubated for $72 \mathrm{~h}$.
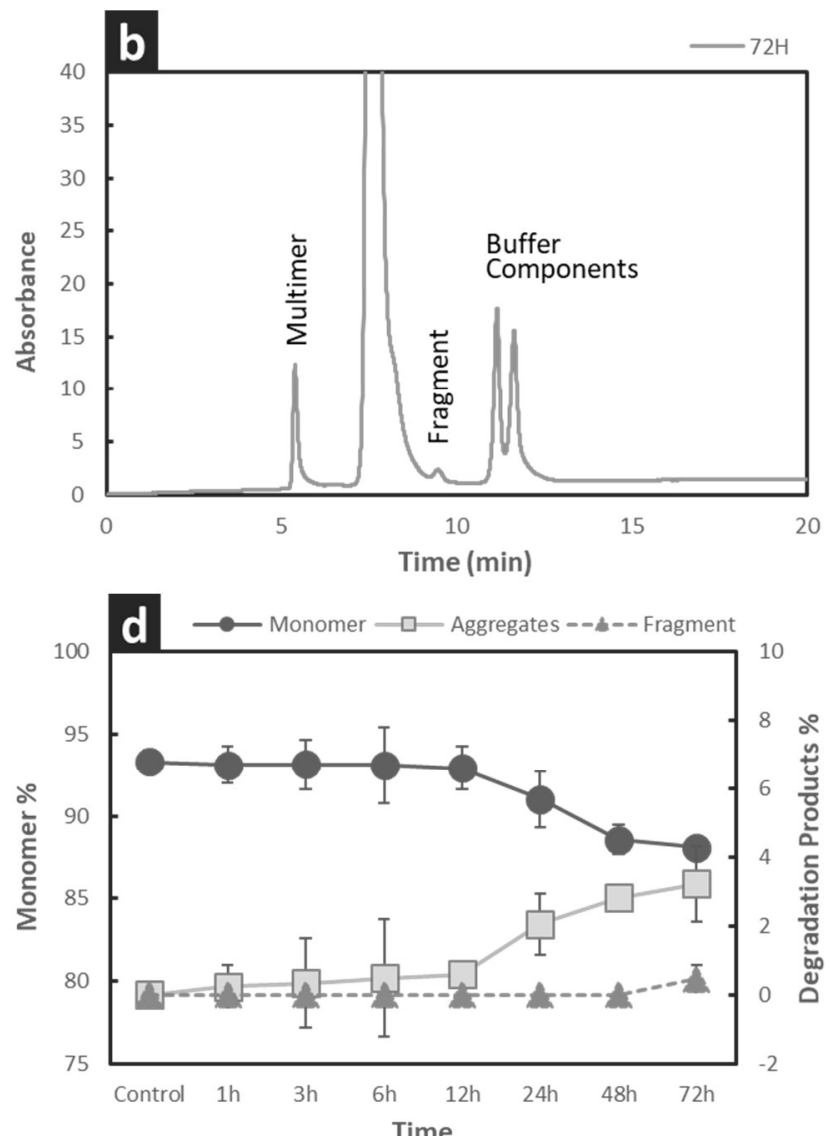
By CEX chromatography, we found no changes in CEX profile of cetuximab exposed to thermal stress. No unknown extra peaks were detected and no changes in the number of isoform peaks and peak area distribution were observed. The recovery values were close to $100 \%$ for all of the stressed samples analysed.

The assessment of cell binding in the samples exposed to the thermal stress showed a marked decrease in the cell binding of cetuximab incubated at this stress condition. As shown in Figure 5a, we observed a decrease in the cell binding of the $\mathrm{mAb}$ incubated at $25{ }^{\circ} \mathrm{C}$ for $48 \mathrm{~h}$. While the cell binding was $95 \%$ for the controls samples, it went down to $88 \%$ in the samples incubated at $25^{\circ} \mathrm{C}$ for $48 \mathrm{~h}$. As shown in the previous section (Figure 3a), we observed a remarkable reduction in cetuximab cell binding when the mAb was exposed to shaking at 25 ${ }^{\circ} \mathrm{C}$ for $48 \mathrm{~h}$. Further analysis reveal that incubation of cetuximab at $25^{\circ} \mathrm{C}$ for longer period of time resulted in more reduction in the cell binding (figure 5a). we also found that incubation of cetuximab at higher temperatures $\left(40^{\circ} \mathrm{C}\right)$ caused more negative impact on its cell binding as compared with what we observed at $25^{\circ} \mathrm{C}$. (Figure $5 b$ ).

Next we evaluated the biological activity of cetuximab under thermal stress. A significant decrease in the biological activity was observed in the mAb samples incubated for a 1 month at $25^{\circ} \mathrm{C}$. While the cell viability in the cells treated with control $\mathrm{mAb}$ was $53 \%$, it went up to $61.8 \%$ in the cells treated with mAb incubated for a month at 25 ${ }^{\circ} \mathrm{C}$ (unpaired students' t-test, $\mathrm{p}<0.05$ ). We did not observe a significant change in the growth inhibitory effects of the mAb incubated at $25{ }^{\circ} \mathrm{C}$ for shorter period of time ( $<$ a month) (Figure $5 \mathrm{c}$ ).

In the next step, cetuximab samples were incubated at a higher temperature (i.e $40{ }^{\circ} \mathrm{C}$ ) and the growth inhibitory effects of the stressed samples was assessed over a one-month period. As depicted in Figure $5 \mathrm{c}$, a significant decrease in $\mathrm{mAb}$ 's potency was detected after just $1 \mathrm{~h}$ incubation at this temperature. The viability of cells increased from $48 \%$ (control group) to $63.1 \%$ and $71 \%$ in the cells treated with $\mathrm{mAb}$ incubated at $40{ }^{\circ} \mathrm{C}$ for $1 \mathrm{~h}$ and 1 month, respectively (unpaired students' t-test, $\mathrm{p}<$ $0.05)$. This indicates that incubation of $\mathrm{mAb}$ at $40^{\circ} \mathrm{C}$ results in a severe alteration in the biologic activity of $\mathrm{mAb}$.

\section{Assessment of cetuximab stability under freeze- thaw cycles}

The next stress condition was multiple freeze-thaw cycles of cetuximab. The obtained results showed that various freeze-thaw cycles made no difference in size exclusion profile of stressed samples in comparison with the control sample. The size exclusion chromatogram indicated no degradation products, as there were no new chromatographic peaks. The recovery of all samples was close to $100 \%$ and the chromatograms of the stressed samples were similar to those of the control samples. Freeze-thaw cycles had also no significant effect on charge heterogeneity profile of the stressed samples comparing to the control one. The chromatograms for the stressed samples were similar to those for the control. The recovery values were close to $100 \%$ for all of the stressed samples analysed.

The evaluation of cell binding in samples exposed to 5 times freeze-thaw determined that freeze-thawing of cetuximab negatively impacted its cell binding capacity. In comparison with the control samples showing the cell binding of $92.6 \%$, the cell binding of mAb samples subjected to freeze-thaw stress for 1, 2, 3, 4 and 5 cycles were 85.6, 84.4, 67.3, 67 and $64.4 \%$ respectively (Figure 6a). Also, the evaluation of growth inhibitory effect of stressed samples showed that while the growth inhibitory effect of $\mathrm{mAb}$ was not significantly affected by 2 times freeze-thaw cycles, it was significantly reduced for the $\mathrm{mAb}$ samples which were freeze thawed for 3 times (unpaired students' t-test, p < 0.05). In comparison with the control group showing the cell viability of $59.4 \%$, the cell viability in the cells treated with the mAb freeze-thawed for 3, 4 and 5 cycles were $72.6 \%, 74.6 \%$ and $78 \%$ respectively (Figure 6b).

\section{The effects of light stress on cetuximab stability}

To evaluate the effects of light on cetuximab, the experiments were performed at four stages according the recommended condition in ICH Q1B photostability guideline. Based on ICH Q1B photostability guideline for New Active Substances and Medicinal Products (3), overall illumination for confirmatory study should not be less than 1.2 million luxh and an integrated near ultraviolet energy of not less than $200 \mathrm{Wh} / \mathrm{m} 2$. Depending on the conformation and structure of the protein and the mechanism of degradation, the proteins undergo varying degrees of instability from mild to too destructive. 

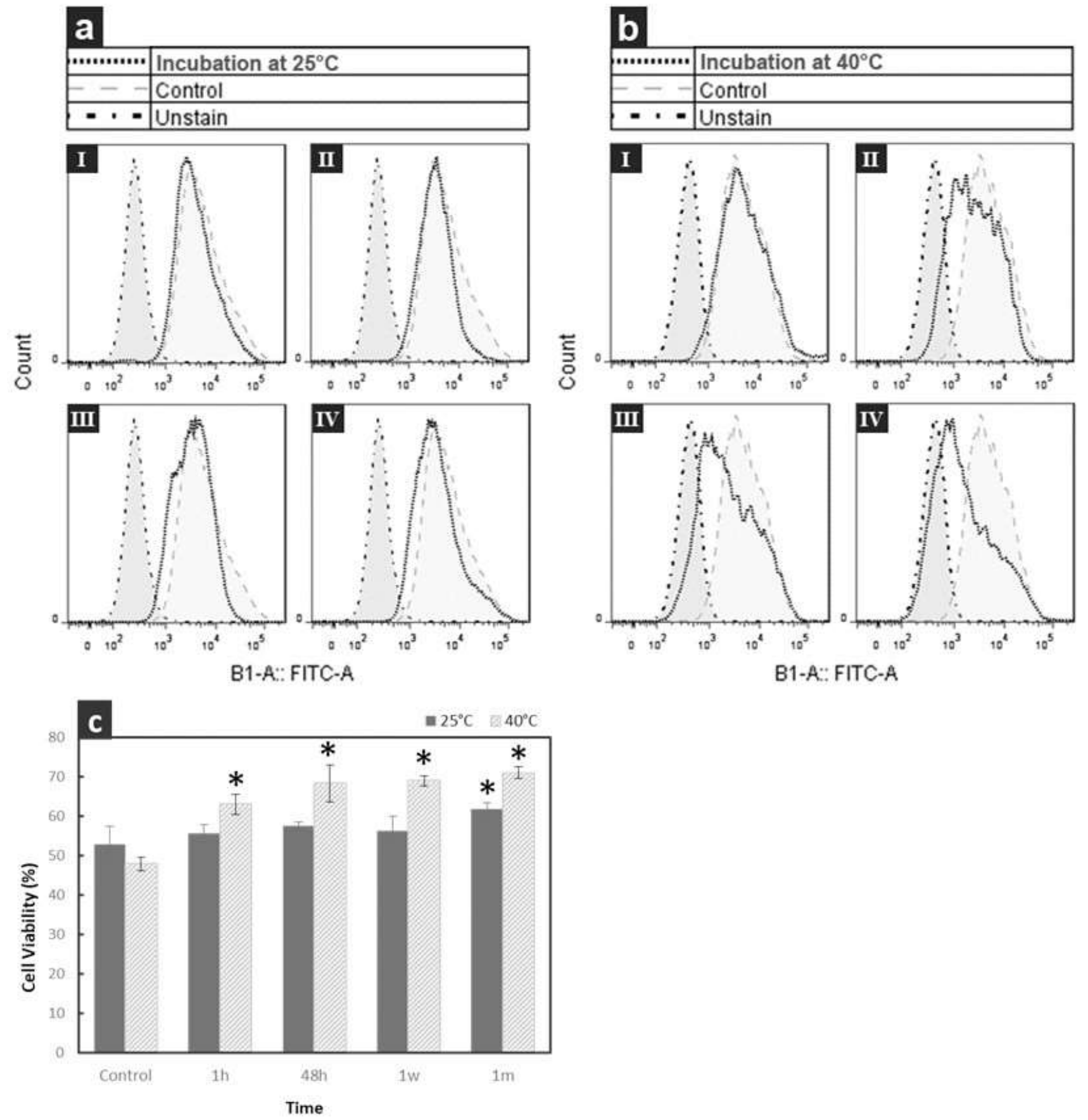

Figure 5. The effects of thermal stress on the bioactivity of cetuximab; Flow cytometric binding assay shows alteration in the cell binding of cetuximab incubated (a) at $25{ }^{\circ} \mathrm{C}$ for I: $1 \mathrm{~h}$; II: $48 \mathrm{~h}$; III: 1 week; IV: 1 month and (b) at $40{ }^{\circ} \mathrm{C}$ for I: $1 \mathrm{~h}$; II: 48 h; III: 1 week; IV: 1 month. The data represent one out of three independent experiments which showed the similar results. (c): Alteration in growth inhibitory effects of cetuximab incubated at 25 and $40{ }^{\circ} \mathrm{C}$, measured by MTS cell viability/proliferation assay. * Significantly different from control (unpaired student's t-test, $\mathrm{p}<0.05$ ).

So, this condition may be inappropriate for all biopharmaceuticals. Consequently, the proper condition should be selected based on molecule by molecule and may need to be optimized in parameters such as light intensity, time duration and wavelength distribution of light.

Analysis of both UVA ( $350 \mathrm{~nm}$ to $400 \mathrm{~nm}$ ) and visible light effect by SEC is presented in Fig 7. The 
preliminary experiments showed that the order of irradiation (UV + visible, or visible + UV) made no significant difference on the test results. No aggregates were detected in the product on day 0 . Results obtained by SEC indicated that light exposure at the first stage $(\geq 0.3$ million luxh and $\geq$ $50 \mathrm{Wh} / \mathrm{m}^{2}$ ) generated an additional peak labeled as dimer eluting before main peak at a retention time of 6. $5 \pm 0.01 \mathrm{~min}$. The second aggregate (labeled as multimer 1) was observed at the second stage $(\geq 0.6$ million luxh and $\geq 100 \mathrm{Wh} / \mathrm{m}^{2}$ ) at retention time of $5.4 \pm 0.02 \mathrm{~min}$ (labeled as multimer). The third aggregate (labeled as multimer 2) and a fragment were detected at the third stage ( $\geq 1.2$ million lux hours and $\geq 200 \mathrm{Wh} / \mathrm{m}^{2}$ ) eluting at $5.8 \pm 0.9 \mathrm{~min}$ and $9.5 \pm 0.9 \mathrm{~min}$ (Figure $7 \mathrm{a}$ ). The AUC of each degraded product slightly increased until the end of the experiment.

The molecular weight of multimers 1,2 , dimer and fragment was calculated to be $852.0 \pm 1.1,628.9$ $\pm 0.8,373.9 \pm 1.5,157.8 \pm 1.4$ and $38.0 \pm 1.1 \mathrm{kDa}$, respectively. Interestingly, degradation products (multimer 1, dimer and fragment) appeared during light exposure had the same retention time and consequently the same molecular weight as the degradation products found under thermal stress at $40^{\circ} \mathrm{C}$.

The multimers and dimer level of the sample exposed to $\geq 1.2$ million lux hours and $\geq 200 \mathrm{Wh} / \mathrm{m}^{2}$ (a required radiation for confirmatory study) increased from the dark control by approximately $1.54 \%$ and $10 \%$, respectively. Therefore, SEC results indicated that light exposure at the ICH guideline level generated a significant amount of dimer and multimer species. Table 1 representing the multimers, dimer and fragment percent in each stage, indicated a marked increase in total aggregates and dimer in the light exposed samples as compared to the dark control.

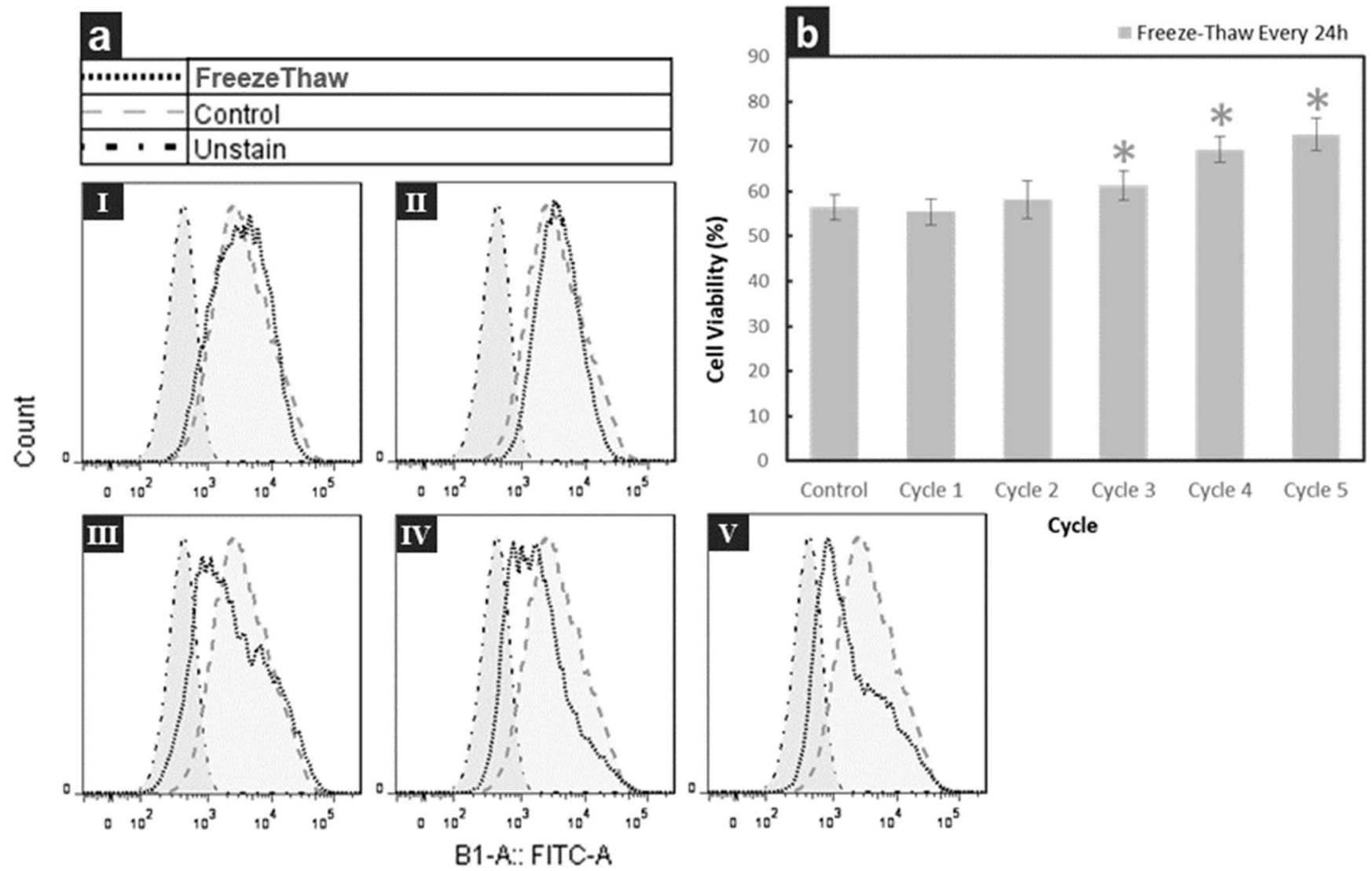

Figure 6. The effects of freeze-thaw on the bioactivity of cetuximab; (a): Flow cytometric binding assay shows alteration in the cell binding of cetuximab subjected to various cycles of freeze-thaw. I: cycle 1, II: cycle 2, III: cycle 3, VI: cycle 4, V: cycle 5. The data represent one out of three independent experiments which showed the similar results. (b): Alteration in bioactivity of cetuximab subjected to various cycles of freeze-thaw measured by MTS cell viability/proliferation assay. * Significantly different from control (unpaired student's t-test, $\mathrm{p}<0.05$ ). 
Table 1. SEC analysis of samples exposed to thermal stress and different intensity of light.

\begin{tabular}{|c|c|c|c|c|c|c|}
\hline Stress condition & $\begin{array}{l}\text { Multimer\% } \\
\text { (Aggregates } \\
\text { 1\&2) }\end{array}$ & $\begin{array}{c}\text { Dimer } \\
\%\end{array}$ & $\begin{array}{c}\text { Total } \\
\text { aggregates } \\
\%\end{array}$ & $\begin{array}{c}\text { Monomer } \\
\text { \% }\end{array}$ & $\begin{array}{c}\text { Fragment } \\
\% \%\end{array}$ & $\begin{array}{c}\text { Buffer } \\
\text { Components } \\
\% \\
\end{array}$ \\
\hline Heat at $40^{\circ} \mathrm{C}$ for 1 month & $0.33 \pm 0.04 *$ & $\begin{array}{c}1.52 \\
\pm 0.04 *\end{array}$ & $\begin{array}{c}1.85 \\
\pm 0.07 *\end{array}$ & $90.05 \pm 1.7$ & $\begin{array}{c}0.83 \\
\pm 0.07^{*}\end{array}$ & $7.27 \pm 0.41$ \\
\hline Heat at $50{ }^{\circ} \mathrm{C}$ for $72 \mathrm{~h}$ & $3.22 \pm 0.05^{*}$ & 0 & $\begin{array}{c}3.22 \\
\pm 0.05 *\end{array}$ & $89.21 \pm 1.9$ & $\begin{array}{c}0.47 \\
\pm 0.03 *\end{array}$ & $7.1 \pm 0.2$ \\
\hline $\begin{array}{l}\text { Light }(\geq 0.3 \text { million luxh } \\
\left.\text { and } \geq 50 \mathrm{Wh} / \mathrm{m}^{2}\right)\end{array}$ & 0 & $\begin{array}{l}3.89 \\
\pm 0.04 *\end{array}$ & $\begin{array}{l}3.89 \\
\pm 0.04 *\end{array}$ & $89.24 \pm 1.4$ & 0 & $6.87 \pm 0.24$ \\
\hline $\begin{array}{l}\text { Light }(\geq 0.6 \text { million luxh } \\
\left.\text { and } \geq 100 \mathrm{Wh} / \mathrm{m}^{2}\right)\end{array}$ & $1.27 \pm 0.04^{*}$ & $\begin{array}{l}7.28 \\
\pm 0.05 *\end{array}$ & $\begin{array}{l}8.55 \\
\pm 0.08 *\end{array}$ & $\begin{array}{l}84.96 \\
\pm 0.8^{*}\end{array}$ & 0 & $6.49 \pm 0.33 *$ \\
\hline $\begin{array}{l}\text { Light }(\geq 1.2 \text { million luxh } \\
\left.\text { and } \geq 200 \mathrm{Wh} / \mathrm{m}^{2}\right)\end{array}$ & $1.54 \pm 0.03 *$ & $\begin{array}{l}10.01 \\
\pm 0.06 *\end{array}$ & $\begin{array}{l}11.55 \\
\pm 0.08 *\end{array}$ & $\begin{array}{l}79.80 \\
\pm 1.5^{*}\end{array}$ & 0 & $7.65 \pm 0.23$ \\
\hline $\begin{array}{l}\text { Light }(\geq 1.8 \text { million luxh } \\
\left.\text { and } \geq 300 \mathrm{Wh} / \mathrm{m}^{2}\right)\end{array}$ & $4.17 \pm 0.04^{*}$ & $\begin{array}{l}10.55 \\
\pm 0.06^{*}\end{array}$ & $\begin{array}{l}14.72 \\
\pm 0.09 *\end{array}$ & $\begin{array}{l}77.77 \\
\pm 1.5^{*}\end{array}$ & $\begin{array}{l}0.96 \\
\pm 0.03 *\end{array}$ & $6.55 \pm 0.17 *$ \\
\hline Dark control & 0 & 0 & 0 & $92.92 \pm 1.1$ & 0 & $7.08 \pm 0.31$ \\
\hline Reference standard & 0 & 0 & 0 & $92.65 \pm 0.9$ & 0 & $7.35 \pm 0.26$ \\
\hline
\end{tabular}

* Significantly different from reference standard (unpaired student's t-test, $\mathrm{p}<0.05$ ).
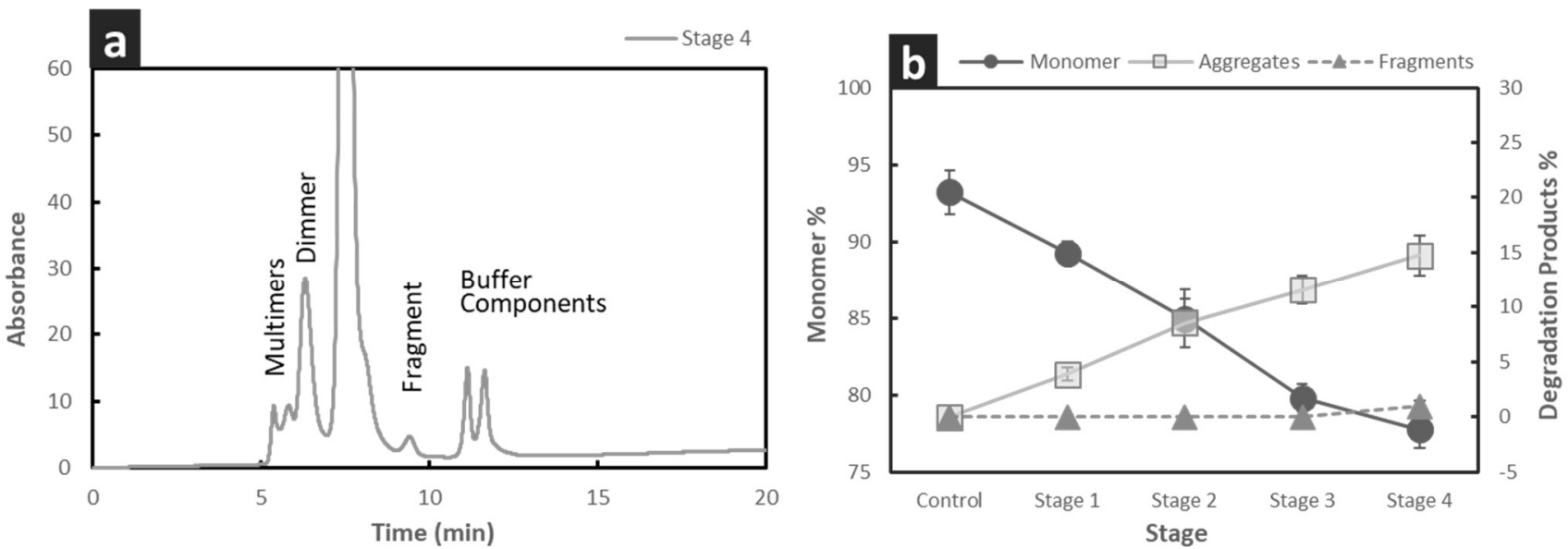

Figure 7. (a): Representative SEC chromatogram monitored at $210 \mathrm{~nm}$ of cetuximab exposed to different levels of light. (b): Plot of monomer loss and soluble aggregates and fragments formation as a function of light exposure measured by SEC.

As previously have reported [24], CEX analysis showed that, the intensity of each peak was decreased at each stage. Also, CEX analysis revealed that receiving $\geq 1.8$ million luxh and $\geq 300 \mathrm{Wh} / \mathrm{m}^{2}$ led to completely loss of intensity of charge variants. Therefore, the experiment was brought to an end at the fourth stage. However, the visual results indicated that the test vials remained colorless and transparent during photo-stability study.

Functional analysis of cetuximab exposed to UV and visible light showed that light stress significantly reduces the bioactivity of this $\mathrm{mAb}$. As depicted in Figure $8 \mathrm{a}$, the cell binding of cetuximab samples exposed to light decreased at each stage of exposure. While the cell binding of the control $\mathrm{mAb}$ was $88.7 \%$, it decreased to $81.4 \%, 79.5 \%, 71.4 \%$ and $62 \%$ at stage $1,2,3$ and 4 of light exposure, respectively. The evaluation of the bioactivity of cetuximab exposed to light showed that the growth inhibitory effects of cetuximab on cancer cells is also extremely affected by the light exposure. As shown in Figure 8b, in comparison with the control sample with cell viability being $52.7 \%$, the viability of the cells treated with mAb exposed to light at stage 1,2, 3 and 4 increased to $60.8 \%, 77.1 \%, 86.3 \%$ and $86.9 \%$, respectively. 


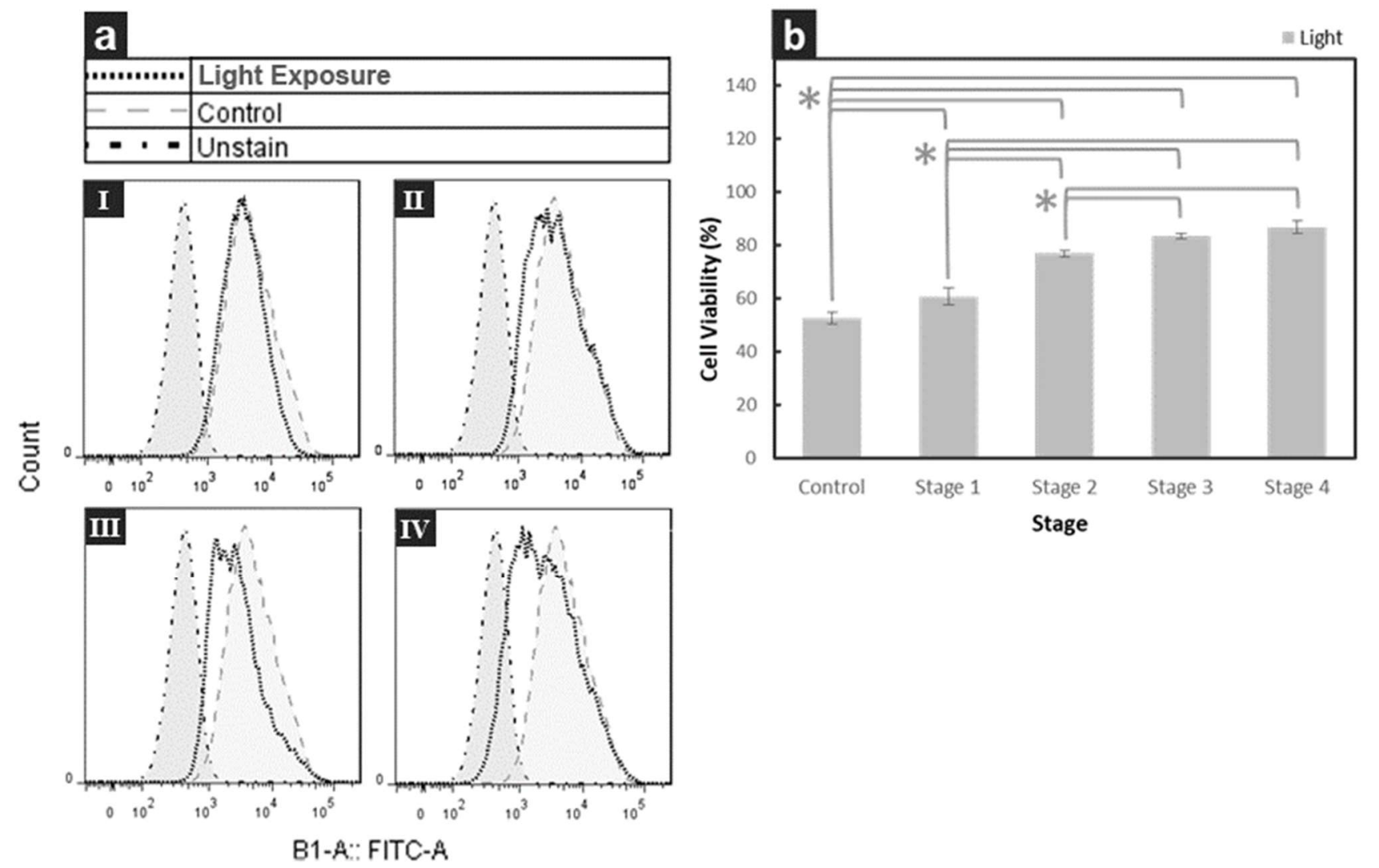

Figure 8. The effects of light exposure on the bioactivity of cetuximab; (a): Flow cytometric binding assay shows alteration in the cell binding of cetuximab exposed to different intensities of light; I: stage $1\left(\geq 0.3 \mathrm{million}\right.$ luxh and $\left.\geq 50 \mathrm{Wh} / \mathrm{m}^{2}\right), \mathrm{II}$ : stage $2\left(\geq 0.6\right.$ million luxh and $\left.\geq 100 \mathrm{Wh} / \mathrm{m}^{2}\right)$, III: stage 3 ( $\geq 1.2$ million luxh and $\left.\geq 200 \mathrm{Wh} / \mathrm{m}^{2}\right)$, IV: stage 4 ( $\geq 1.8 \mathrm{million}$ luxh and $\geq 300 \mathrm{Wh} / \mathrm{m}^{2}$ ). (b): Alteration in bioactivity of cetuximab exposed to different intensities of light measured MTS cell viability/proliferation assay. * Significantly different (one-way ANOVA followed by Tukey test, $\mathrm{p}<0.05$ ).

\section{DISCUSSION}

In this research we have evaluated the stability and bioactivity of cetuximab exposed to four different stress conditions (shaking, high temperature, multiple freeze-thaw cycles, and light exposure). Our findings show that among the stress conditions studied in this project, the light exposure caused physicochemical instability of cetuximab and significantly impacted its biological function. The other stress conditions including freeze-thawing, mechanical stress, and moderate thermal stress (incubation at $25{ }^{\circ} \mathrm{C}$ ) had no effects on the physicochemical properties of cetuximab. However, these stress conditions significantly reduced cetuximab bioactivity indicated by a decrease in its ability to bind to its receptor and inhibit cancer cells growth. Our results highlight the importance of performing bioassays in parallel with physicochemical techniques in stability and quality control studies of biopharmaceuticals.

Mechanical stress generated by shaking is a convenient method to monitor and evaluate the robustness of biopharmaceutical formulation. During mechanical stress testing, proteins are encountered several stress factors, such as exposure to liquid-air, liquid-container interfaces, shearing, cavitation, and local warming effects (28). These stress factors can result in physical and chemical instability. Shaking causes an increase in the frequency of protein exposure to hydrophobic surfaces or air/water interfaces leading to the formation of aggregates. In this research, mechanical stability of cetuximab was assessed by incubating the $\mathrm{mAb}$ at 4 and $25{ }^{\circ} \mathrm{C}$ for $48 \mathrm{~h}$ while exposing the sample to shaking with intensities of 150 and 250 $\mathrm{rpm}$. Interestingly, exposure of the mAb samples to the specified mechanical stress condition did not result in generation of any degraded product and had 
no negative effect on size exclusion profile of stressed samples as compared with the control. Furthermore, evaluation of chemical stability of the mAb sample by the CEX method revealed no new acidic or basic variants appearance and no modification in charge profile of stressed samples in comparison with the control one. Consistent with our results, M. Kupfer et al reported that Alemtuzumab in infusion bags remained physically and chemically stable, when stored on a vibrating plate over 14 days (37). Polysorbate as a nonionic surfactant are commonly used in protein formulations to prevent mechanically-induced aggregation (38). Each singleused Erbitux and Araxya vial contains the cetuximab along with polysorbate 80 and other inactive ingredient. Polysorbate accumulates at the air-liquid interface and protects the protein against shaking stress. Mahler et al. reported that $0.005 \% \mathrm{w} / \mathrm{v}$ concentration of a polysorbate prevents formation of aggregates in each protein concentration (28). Lahlou et al. have reported that stirring of cetuximab (Merck Lipha Santé, France) at $700 \mathrm{rpm}$ for $24 \mathrm{~h}$ in controlled ambient temperature $\left(20 \pm 1{ }^{\circ} \mathrm{C}\right)$ causes formation of insoluble aggregate due to a decrease in total AUC of mAb monomer without any additional peak in size chromatograms. As mentioned earlier, aggregates are formed as a results of an increased exposure of molecules to air/liquid interface (24). Obviously, the shaking intensity of $700 \mathrm{rpm}$ is more intense than mechanical stress conditions which the mAbs product may exposed to during storage, transportation and shipping. Therefore, to mimic the most probable shaking stress conditions on biopharmaceuticals, the intensities of 150 and 250 rpm were selected in this study.

In contrast to what we observed on the impact of mechanical stress on physicochemical properties of cetuximab, we found a marked decrease in the binding of cetuximab to its target receptor when it was exposed to mechanical stress (shaking with intensities of 150 and $250 \mathrm{rpm}$ ) at room temperature $\left(25^{\circ} \mathrm{C}\right)$. These findings are correlated with what we observed in evaluating the growth inhibitory of the $\mathrm{mAb}$ exposed to shaking stress at $25{ }^{\circ} \mathrm{C}$. The negative impact of mechanical stress on bioactivity of cetuximab was found to be more severe when the sample was exposed to shaking stress at $25{ }^{\circ} \mathrm{C}$ as compared with what was observed for the samples exposed to mechanical stress at $4{ }^{\circ} \mathrm{C}$. This finding suggests that high temperature might have intensified the negative effects of shaking stress on the mAb bioactivity. Therapeutic antibodies can undergo shaking stress during transportation and our results show that the exposure of cetuximab to shaking stress at $4{ }^{\circ} \mathrm{C}$ doesn't impact its biological activity, which is indicated by insignificant changes in the cytotoxicity of the stressed samples in cancer cells as compared with the control group. This finding suggests that this product need to be kept refrigerated during transportation.

Thermal stress is another prevalent stress condition which causes degradation of therapeutic proteins which are usually recommended to be stored in the refrigerator $\left(2-8^{\circ} \mathrm{C}\right)$. $\mathrm{mAbs}$ can be exposed to the temperatures higher than the recommended one during production, shipment, storage, and final administration. For thermal stress testing, selection of a suitable temperature should be done on a caseby-case approach. Based on U.S. Pharmacopeia (USP) classification for different storage conditions, we did the thermal stress studies at $25{ }^{\circ} \mathrm{C}$ (room temperature), $30^{\circ} \mathrm{C}$ (upper limit of controlled room temperature), $40^{\circ} \mathrm{C}$ (upper limit of warm) and $50^{\circ} \mathrm{C}$ (excessive heat). Incubation of samples at 25 and 30 ${ }^{\circ} \mathrm{C}$ for 1 month didn't result in any physical or chemical instability in the mAb. The SEC method did not show polymerization or fragmentation, and no change in retention time and AUC was detected for the control and stressed samples. No additional peak or decrease in the AUC was found by the CEX method. In line with our observation, M. Kupfer et al reported that Alemtuzumab incubated at room temperature remained physically and chemically stable over 14 days (37).

Contrary to what we found on the physicochemical stability of cetuximab exposed to the moderate thermal stress (incubation at $25^{\circ} \mathrm{C}$ ), a significant decrease in the bioactivity of the $\mathrm{mAb}$ was observed in the $\mathrm{mAb}$ samples were incubated at $25{ }^{\circ} \mathrm{C}$ for 1 month. We didn't observe any changes in the bioactivity of cetuximab incubated at $25^{\circ} \mathrm{C}$ for a week. This means that the accidental exposure of the product to room temperature for a short period of time during storage by either the product provider or the patient may not cause any significant change in the therapeutic efficacy of the product.

Exposure of cetuximab samples to severe thermal stress condition (incubation at $40{ }^{\circ} \mathrm{C}$ ) led to generation of aggregates which formed after a week incubation at $40{ }^{\circ} \mathrm{C}$ and $1 \mathrm{~h}$ incubation at $50{ }^{\circ} \mathrm{C}$. Since elevated temperature perturbs the native conformation of protein to a proper degree, high temperature leads to physical degradation and in many cases leads to irreversible denaturation due to 
aggregate formation. Aggregation begins to form at temperatures below the equilibrium melting temperature and partially unfolded protein molecules which are the reactive species cause to form aggregation (29). Irreversible conformational changes were induced in the bevacizumab's structure by the increase of temperature leading to an unfolded state (39). In addition, thermal stress causes to fragmentation of antibodies (40). In this research, the SEC method also detected a fragment formation, which was present after a weak incubation at $40{ }^{\circ} \mathrm{C}$ and $72 \mathrm{~h}$ at $50{ }^{\circ} \mathrm{C}$. Consistent with our results, incubation of rituximab monoclonal antibody for six months at $40{ }^{\circ} \mathrm{C}$ led to fragmentation which was coherent with the release of light chains (41). Under variety of stress condition such as thermal treatment (42), freeze-thaw, acidic and basic treatment (43), antibodies can simply loose a Fab arm, a light chain and separated heavy chain and light-chain lead to form fragmentation.

Moreover, as expected the incubation of cetuximab at $40{ }^{\circ} \mathrm{C}$ resulted in a severe decrease in the bioactivity $\mathrm{mAb}$. Our findings also reveal a timedependent decrease in binding property of cetuximab exposed to high temperature. Also decrease in biological activity of mAb appeared to be temperature-dependent such that exposure to the higher temperature resulted in more decrease in bioactivity. Decrease in the biological activity of the samples exposing $40{ }^{\circ} \mathrm{C}$ is correlated with what we observed with SEC method on the physicochemical stability of cetuximab exposed to this stress condition. In line with our results, Muriel Paul et al reported that the incubation of rituximab at $40{ }^{\circ} \mathrm{C}$ led to generation of HMWs and a fragment detected by the SEC method and loss of $50 \%$ of its biological activity (41).

We also assessed the stability of cetuximab under various freeze-thaw cycles. Freeze-thawing a protein solution generates several stress factors which can cause aggregation (44). These stress factors include cold denaturation of proteins related to an increase in solubility of hydrophobic residues due to low temperature, adsorbtion to the ice-liquid interface or to the container surface, a drop in the formulation $\mathrm{pH}$ during freezing and perturbation of the protein by cryoconcentration of protein are effective factors in aggregation formation (45). Similar to our observation on the effects of mechanical and moderate thermal stress on cetuximab physicochemical stability, the chromatographic evaluation revealed no change in size exclusion and cation exchange profile of $\mathrm{mAb}$ samples undergone multiple freeze-thawing cycles. This observation showed that the undiluted cetuximab at concentration of $5 \mathrm{mg} / \mathrm{mL}$ was physically and structurally resistant to freeze-thaw stress. Martínez-Ortega et al have demonstrated that the chromatographic analysis of the undiluted cetuximab $5 \mathrm{mg} / \mathrm{mL}$ frozen at $-20^{\circ} \mathrm{C}$ over a 15 days period revealed the absence of any kind of aggregates (46). Physical stability of cetuximab against various freeze-thaw cycles may be partially result of an inherent structural stability of cetuximab molecule and partially related to the preventive effect of formulation components.

In line with what we observed for the bioactivity of the samples exposed to mechanical and moderate thermal stress, freeze-thawing of cetuximab for 3 times significantly impacted its bioactivity. Three cycles of freeze-thawing markedly reduced the cell binding and growth inhibitory effects of cetuximab in A431 cells as compared with what observed for the control sample. These results suggest that the analytical methods to assess long-term physicochemical stability of mAbs they should be accompanied by bioassays in the quality control processes of these biopharmaceuticals. No change in the bioactivity of cetuximab was observed when the mAb samples which were undergone twice freezthawing, suggesting that accidental freeze-thawing of the product once or twice will not significanclty impact its therapeutic efficacy.

Finally, we evaluated the impact of light stress on cetuximab stability and found that the light stress causes physicochemical instability and negatively impact the bioactivity of this mAb. Exposure of the $\mathrm{mAb}$ samples to UV and visible light resulted in a significant physicochemical instability indicated by generation of multimers, dimer and a fragment which are detected by the SEC method. Interestingly, degradation products (multimer 1, dimer and fragment) appeared during light exposure had the same retention time and consequently the same molecular weight as the degradation products found under thermal stress at $40{ }^{\circ} \mathrm{C}$. Consistent with our results, Jose Hernandez-Jimenez and et al reported that the light exposure to Erbitux (cetuximb, Merck KGaA, Germany) led to the formation of dimer (25). The slight differences in the number of degradation products between our observations and the reported findings might be related to the differences in formulation composition, wavelength, intensity, and duration of light exposure. P.Qi et al have also 
reported that photo-degradation of highconcentration liquid dosage form of a human $\mathrm{IgG}_{1}$ monoclonal antibody led to the formation of two aggregate species corresponding to dimer and trimer and one fragment specie detected by the SEC (47). In support of these findings, previous studies have shown that the oxidation of light sensitive amino acids such as Tryptophan (Trp), Tyrosine (Tyr) and Phenylalanine (Phe) under light exposure causes physical instability and aggregation of biopharmaceuticals (12). It has been also reported that the exposure of $\mathrm{IgG}_{1}$ monoclonal antibody to UV light results in formation of a HMWs dependent on $\mathrm{pH}$ of formulation, where an increase in $\mathrm{pH}$ of formulation results in increasing the oligomerization's degree of degradation products (48).

We also observed significant modifications in the charge profile of cetuximab exposed to different intensity of light, when the samples were analyzed by CEX method. CEX analysis of the mAb showed no new acidic or basic variants appeared, however a significant decrease in the intensity of peaks was observed for the mAb samples exposed to the light in all four stages. Decrease in intensity of peaks indicated a change in charge heterogeneity profile of cetuximab probably due to degradation of molecule. Therefore, chemical instability appeared to be the most critical point in this condition, as after light exposure, important chemical modifications were revealed by the CEX. This highlights the necessity of protection of cetuximab from light in the secondary packaging (26). Various parameters are involved in light-induced degradation such as structure and conformation of protein, formulation excipients, and primary packaging, as well as wavelength, light intensity, and time exposure. Although the experiments have to be performed using ICH conditions but, the appropriate conditions may need to be determined on a molecule by molecule basis and may require optimization of times and strength of light to obtain more meaningful result.

The change in charge heterogeneity profile of a protein exposed to light stress can be contributed to potential change in charge distribution on the surface of protein. Alteration in the local distribution of charged residue as a result of even small perturbations in the protein structure causes changes in the overall surface charge distribution of the molecule (49). As mentioned earlier, Trp, Tyr and Phe (the aromatic amino acids) and Cystein (Cys, the peptide backbone) are the most sensitive structural components to light induced degradation which causes the formation of reactive oxygen species and primarily results in chemical alteration in amino acids. Furthermore, light exposure can lead to dityrosine or disulfide formation by multiple crosslinking reactions and to noncovalent aggregation (50). Also, Exposure to light of biopharmaceuticals containing polysorbate 80 in their formulation as Araxya causes the formation of hydroperoxide derivatives and oxidative damage to the protein structure in the formulation (51). It should be considered that polysorbate 80 plays a key role in protecting the formulation against mechanical stress.

Correlating with the results of physicochemical studies, the cell binding capacity of cetuximab exposed to the light was significantly reduced as compared with that of control sample. The binding surface of cetuximab is rich in Tyr and Trp, typically found in antibody combining sites (52), so chemical alteration in these amino acids is expected to result in a decrease in mAbs cell binding (50). Consistent with our observation on the binding property of samples subjected to light, the growth inhibitory effects of the stressed samples on cancer cells also significantly decreased at each stage of light exposure. Altogether these findings show that light exposure impact the physicochemical properties and biological function of cetuximab suggesting the $\mathrm{mAb}$ need to be protected from light during packaging, shipment, and storage. Our results show that cetuximab is sensitive to light and must to be protected from light during production, transportation, storage, and usage.

\section{CONCLUSION}

To conclude, physicochemical and biological characterization of cetuximab exposed to various stress condition showed that the mild stress conditions do not influence physicochemical and biological properties of cetuximab. The mild stress conditions include incubation for a week at $25{ }^{\circ} \mathrm{C}$, shaking at refrigerated condition, and 2 times freezethawing. Our findings showed that the most destructive effects on cetuximab stability are caused by exposure to light and incubation at $40{ }^{\circ} \mathrm{C}$. Based on our observations the exposure of cetuximab to light or incubation of cetuximab at $40{ }^{\circ} \mathrm{C}$ results in physicochemical instability as well as a severe decrease in its biological activity. We also found that the finish product of cetuximab $(5 \mathrm{mg} / \mathrm{mL})$ remains physicochemically stable when it is exposed to 
mechanical stress (150 and $250 \mathrm{rpm}$ shaking for 48 h), incubation at $25{ }^{\circ} \mathrm{C}$ for 1 month with/without shaking stress, and freeze-thawing (5 cycles). However, bioactivity of the commercially available cetuximab was significantly reduced when was exposed to the above specified thermal and mechanical stress conditions. Our observation that some stress conditions that do not alter physicochemical properties of cetuximab, but reduce the biological activity of the drug, emphasizes the necessity of performing appropriate bioassay methods in addition to physicochemical techniques as recommended by ICH Q5C guideline for quality control of biopharmaceuticals.

\section{ACKNOWLEDGMENTS}

This work is a part of A. Farjami thesis, submitted for PhD degree and supported by Research Council, Tabriz University of Medical Sciences. We would like to thank the CinnaGen Medical Biotechnology Center for kindly providing all of the cetuximab medicinal samples.

\section{COMPLIANCE WITH ETHICAL STANDARDS}

\section{Conflict of Interest}

The authors state no conflict of interest.

\section{Research Involving Human Participants and/or Animals}

This article does not contain any studies with human participants or animals performed by any of the authors.

\section{REFERENCES}

1. Beck A, Wurch T, Bailly C, Corvaia N. Strategies and challenges for the next generation of therapeutic antibodies. Nature reviews Immunology. 2010;10(5):345-52. DOI:10.1038/nri2747

2. Scolnik PA. mAbs: a business perspective. mAbs. 2009;1(2):179-84

3. Guideline ICH Q1B, Stability testing: photostability testing of new drug substances and products. Current Step1996.

4. Sparrow E, Friede M, Sheikh M, Torvaldsen S. Therapeutic antibodies for infectious diseases. Bulletin of the World Health Organization. 2017;95(3):235-7. DOI:10.2471/blt.16.178061

5. Bhutani D, Vaishampayan UN. Monoclonal antibodies in oncology therapeutics: present and future indications. Expert opinion on biological therapy.

DOI:10.1517/14712598.2012.758705

6. Deiss A, Brecht I, Haarmann A, Buttmann M. Treating multiple sclerosis with monoclonal antibodies: a 2013 update. Expert review of neurotherapeutics.

DOI:10.1586/ern.13.17

7. Oliva A, Llabres M, Farina JB. Fitting bevacizumab aggregation kinetic data with the Finke-Watzky twostep model: Effect of thermal and mechanical stress. European journal of pharmaceutical sciences : official journal of the European Federation for Pharmaceutical Sciences. 2015;77:170-9. DOI:10.1016/j.ejps.2015.06.011

8. Vigneron J, Astier A, Trittler R, Hecq JD, Daouphars $\mathrm{M}$, Larsson I, et al. SFPO and ESOP recommendations for the practical stability of anticancer drugs: an update. Annales pharmaceutiques francaises. 2013;71(6):376-89. DOI:10.1016/j.pharma.2013.06.002

9. Bardin C, Astier A, Vulto A, Sewell G, Vigneron J, Trittler R, et al. Guidelines for the practical stability studies of anticancer drugs: a European consensus conference. Annales pharmaceutiques francaises. 2011;69(4):221-31.

DOI:10.1016/j.pharma.2011.07.002

10. Kane CD, Nuss JE, Bavari S. Novel therapeutic uses and formulations of botulinum neurotoxins: a patent review (2012 - 2014). Expert opinion on therapeutic patents. 2015;25(6):675-90. DOI:10.1517/13543776.2015.1030337

11. Schellekens H, Jiskoot W. Immunogenicity of therapeutic proteins. In: Crommelin D. SR, Meibohm B., editor. Pharmaceutical biotechnology: Springer, New York, NY; 2013. p. 133-41.

12. Manning MC, Chou DK, Murphy BM, Payne RW, Katayama DS. Stability of protein pharmaceuticals: an update. Pharmaceutical research. 2010;27(4):54475. DOI:10.1007/s11095-009-0045-6

13. Wang W. Instability, stabilization, and formulation of liquid protein pharmaceuticals. International journal of pharmaceutics. 1999;185(2):129-88

14. Luo Q, Joubert MK, Stevenson R, Ketchem RR, Narhi LO, Wypych J. Chemical modifications in therapeutic protein aggregates generated under different stress conditions. The Journal of biological chemistry. 2011;286(28):25134-44. DOI:10.1074/jbc.M110.160440

15. Carpenter JF, Randolph TW, Jiskoot W, Crommelin DJ, Middaugh CR, Winter G, et al. Overlooking subvisible particles in therapeutic protein products: gaps that may compromise product quality. Journal of pharmaceutical sciences. 2009;98(4):1201-5. DOI:10.1002/jps.21530

16. Longstaff C, Whitton CM, Stebbings R, Gray E. How do we assure the quality of biological medicines? 
Drug discovery today. 2009;14(1-2):50-5. DOI:10.1016/j.drudis.2008.09.010

17. Wong S-F. Cetuximab: an epidermal growth factor receptor monoclonal antibody for the treatment of colorectal cancer. Clinical therapeutics. 2005;27(6):684-94.

DOI:10.1016/j.clinthera.2005.06.003

18. Rizzo S, Bronte G, Fanale D, Corsini L, Silvestris N, Santini D, et al. Prognostic vs predictive molecular biomarkers in colorectal cancer: is KRAS and BRAF wild type status required for anti-EGFR therapy? Cancer treatment reviews. 2010;36 Suppl 3:S56-61. DOI:10.1016/s0305-7372(10)70021-9

19. van Krieken JH, Jung A, Kirchner T, Carneiro F, Seruca R, Bosman FT, et al. KRAS mutation testing for predicting response to anti-EGFR therapy for colorectal carcinoma: proposal for an European quality assurance program. Virchows Archiv : an international journal of pathology. 2008;453(5):41731. DOI:10.1007/s00428-008-0665-y

20. Shigeta K, Hayashida T, Hoshino Y, Okabayashi K, Endo T, Ishii $\mathrm{Y}$, et al. Expression of Epidermal Growth Factor Receptor Detected by Cetuximab Indicates Its Efficacy to Inhibit In Vitro and In Vivo Proliferation of Colorectal Cancer Cells. PloS one. 2013;8(6):e66302.

DOI:10.1371/journal.pone.0066302

21. Lievre A, Bachet J-B, Le Corre D, Boige V, Landi B, Emile J-F, et al. KRAS mutation status is predictive of response to cetuximab therapy in colorectal cancer. Cancer research. 2006;66(8):3992-5. DOI:10.1158/0008-5472.CAN-06-0191

22. Carmen J, Burger SR, McCaman M, Rowley JA. Developing assays to address identity, potency, purity and safety: cell characterization in cell therapy process development. Regenerative medicine. 2012;7(1):85-100. DOI:10.2217/rme.11.105

23. Bravery CA, Carmen J, Fong T, Oprea W, Hoogendoorn KH, Woda J, et al. Potency assay development for cellular therapy products: an ISCT review of the requirements and experiences in the industry. Cytotherapy. 2013;15(1):9-19. DOI:10.1016/j.jcyt.2012.10.008

24. Lahlou A, Blanchet B, Carvalho M, Paul M, Astier A. Mechanically-induced aggregation of the monoclonal antibody cetuximab. Annales pharmaceutiques francaises. 2009;67(5):340-52. DOI:10.1016/j.pharma.2009.05.008

25. Hernandez-Jimenez J, Salmeron-Garcia A, Cabeza J, Velez C, Capitan-Vallvey LF, Navas N. The Effects of Light-Accelerated Degradation on the Aggregation of Marketed Therapeutic Monoclonal Antibodies Evaluated by Size-Exclusion Chromatography With Diode Array Detection. Journal of pharmaceutical sciences. 2016;105(4):1405-18. DOI:10.1016/j.xphs.2016.01.012
26. Farjami A, Siahi-Shadbad M, Akbarzadehlaleh P, Molavi O. Development and Validation of Salt Gradient CEX Chromatography Method for Charge Variants Separation and Quantitative Analysis of the IgG mAb-Cetuximab. Chromatographia. 2018:1-12. DOI:10.1007/s10337-018-3627-9

27. Farjami A, Akbarzadehlaleh P, Molavi O, SiahiShadbad M. Stability-Indicating Size Exclusion Chromatography Method for the Analysis of IgG mAb-Cetuximab. Chromatographia. 2019:1-10

28. Mahler HC, Friess W, Grauschopf U, Kiese S. Protein aggregation: pathways, induction factors and analysis. Journal of pharmaceutical sciences. 2009;98(9):2909-34. DOI:10.1002/jps.21566

29. Wang W, Singh S, Zeng DL, King K, Nema S. Antibody structure, instability, and formulation. Journal of pharmaceutical sciences. 2007;96(1):1-26. DOI:10.1002/jps.20727

30. Philo JS. Is any measurement method optimal for all aggregate sizes and types? The AAPS journal. 2006;8(3):E564-71. DOI:10.1208/aapsj080365

31. Vermeer AW, Norde W. The thermal stability of immunoglobulin: unfolding and aggregation of a multi-domain protein. Biophysical journal. 2000;78(1):394-404. DOI:10.1016/s00063495(00)76602-1

32. Guideline ICH Q5C, Stability Testing of Biotechnological/Biological products. 1995. p. 1-8.

33. Robinson CJ, Jones C. Quality control and analytical techniques for biopharmaceuticals. Bioanalysis. 2011;3(1):81-95. DOI:10.4155/bio.10.161

34. O'Hara DM, Xu Y, Liang Z, Reddy MP, Wu DY, Litwin V. Recommendations for the validation of flow cytometric testing during drug development: II assays. Journal of immunological methods. 2011;363(2):120-34. DOI:10.1016/j.jim.2010.09.036

35. Li S, Schmitz KR, Jeffrey PD, Wiltzius JJ, Kussie P, Ferguson KM. Structural basis for inhibition of the epidermal growth factor receptor by cetuximab. Cancer cell. 2005;7(4):301-11. DOI:10.1016/j.ccr.2005.03.003

36. Zinsky R, Bolukbas S, Bartsch H, Schirren J, Fisseler-Eckhoff A. Analysis of KRAS Mutations of Exon 2 Codons 12 and 13 by SNaPshot Analysis in Comparison to Common DNA Sequencing. Gastroenterology research and practice. 2010;2010:789363. DOI:10.1155/2010/789363

37. Kupfer M, Scriba G, Hartmann M. Stability of alemtuzumab in infusion-bags. Die Pharmazie-An International Journal of Pharmaceutical Sciences. 2009;64(9):622-3

38. Wang W, Wang YJ, Wang DQ. Dual effects of Tween 80 on protein stability. International journal of pharmaceutics. 2008;347(1-2):31-8. DOI:10.1016/j.ijpharm.2007.06.042

39. Sousa F, Sarmento B, Neves-Petersen MT. Biophysical study of bevacizumab structure and 
bioactivity under thermal and $\mathrm{pH}$-stresses. European journal of pharmaceutical sciences : official journal of the European Federation for Pharmaceutical Sciences. 2017;105:127-36. DOI:10.1016/j.ejps.2017.05.019

40. Vermeer AW, Norde W, van Amerongen A. The unfolding/denaturation of immunogammaglobulin of isotype $2 \mathrm{~b}$ and its $\mathrm{F}(\mathrm{ab})$ and $\mathrm{F}(\mathrm{c})$ fragments. Biophysical journal. 2000;79(4):2150-4. DOI:10.1016/s0006-3495(00)76462-9

41. Paul M, Vieillard V, Jaccoulet E, Astier A. Long-term stability of diluted solutions of the monoclonal antibody rituximab. International journal of pharmaceutics. 2012;436(1-2):282-90. DOI:10.1016/j.ijpharm.2012.06.063

42. Alexander AJ, Hughes DE. Monitoring of $\operatorname{IgG}$ antibody thermal stability by micellar electrokinetic capillary chromatography and matrix-assisted laser desorption/ionization mass spectrometry. Analytical chemistry. 1995;67(20):3626-32

43. Usami A, Ohtsu A, Takahama S, Fujii T. The effect of $\mathrm{pH}$, hydrogen peroxide and temperature on the stability of human monoclonal antibody. J Pharm Biomed Anal. 1996;14(8-10):1133-40

44. Bhatnagar BS, Bogner RH, Pikal MJ. Protein stability during freezing: separation of stresses and mechanisms of protein stabilization. Pharmaceutical development and technology. 2007;12(5):505-23. DOI:10.1080/10837450701481157

45. Hawe A, Kasper JC, Friess W, Jiskoot W. Structural properties of monoclonal antibody aggregates induced by freeze-thawing and thermal stress. European journal of pharmaceutical sciences : official journal of the European Federation for
Pharmaceutical Sciences. 2009;38(2):79-87. DOI:10.1016/j.ejps.2009.06.001

46. Martínez-Ortega A, Salmerón-García A, NavasIglesias N, Hernández-Jiménez J, Cabeza-Barrera J, Capitán-Vallvey L. TCH-026 Long-Term Study of the Formation of Aggregates in Undiluted Cetuximab $5 \mathrm{mg} / \mathrm{ml}$. European Journal of Hospital Pharmacy: Science and Practice. 2013;20(Suppl 1):A78-A. DOI:10.1136/ejhpharm-2013-000276.217

47. Qi P, Volkin DB, Zhao H, Nedved ML, Hughes R, Bass $R$, et al. Characterization of the photodegradation of a human IgG1 monoclonal antibody formulated as a high-concentration liquid dosage form. Journal of pharmaceutical sciences. 2009;98(9):3117-30. DOI:10.1002/jps.21617

48. Mason BD, Schoneich C, Kerwin BA. Effect of $\mathrm{pH}$ and light on aggregation and conformation of an IgG1 mAb. Molecular pharmaceutics. 2012;9(4):774-90. DOI:10.1021/mp2004719

49. Vlasak J, Ionescu R. Heterogeneity of monoclonal antibodies revealed by charge-sensitive methods. Current pharmaceutical biotechnology. 2008;9(6):468-81

50. Kerwin BA, Remmele RL, Jr. Protect from light: photodegradation and protein biologics. Journal of pharmaceutical sciences. 2007;96(6):1468-79. DOI:10.1002/jps.20815

51. Singh SR, Zhang J, O'Dell C, Hsieh MC, Goldstein J, Liu J, et al. Effect of polysorbate 80 quality on photostability of a monoclonal antibody. AAPS PharmSciTech. 2012;13(2):422-30. DOI:10.1208/s12249-012-9759-6

52. Lo Conte L, Chothia C, Janin J. The atomic structure of protein-protein recognition sites. Journal of molecular biology. 1999;285(5):2177-98 